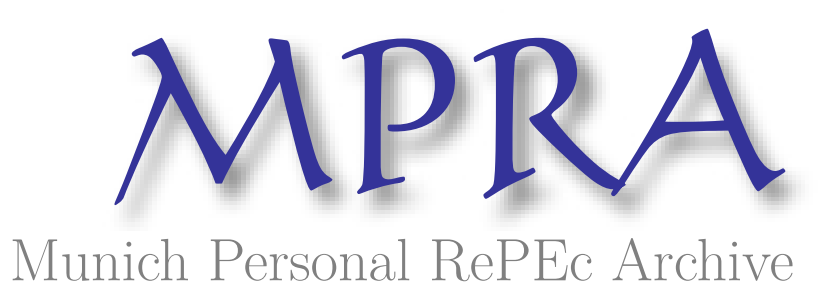

\title{
International Competitiveness, Multinational Enterprise Technology Clubs and the Government Interface
}

Gilroy, Bernard Michael

1998

Online at https://mpra.ub.uni-muenchen.de/17983/

MPRA Paper No. 17983, posted 26 Oct 2009 09:03 UTC 


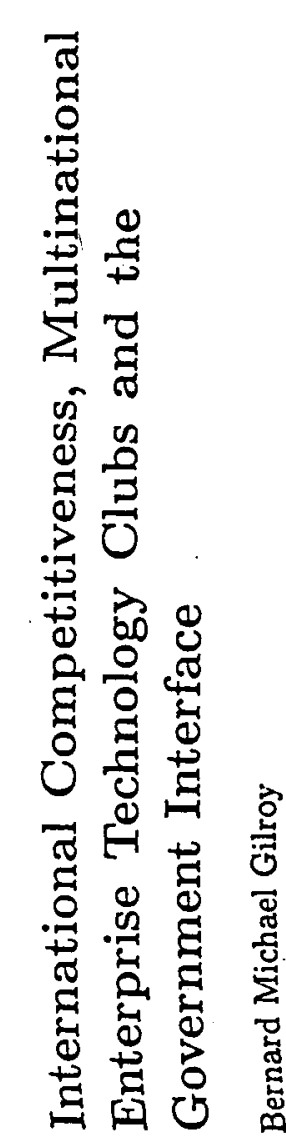

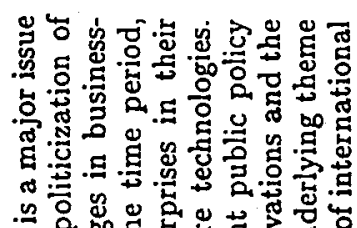

응

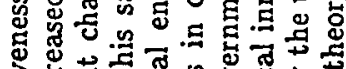

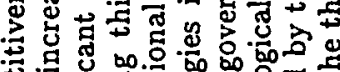

正

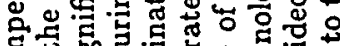

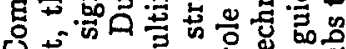

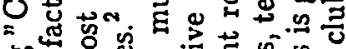

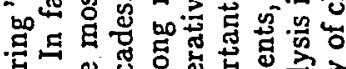

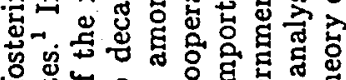

过

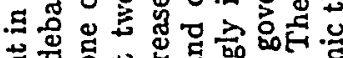

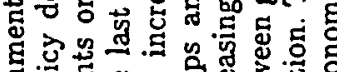

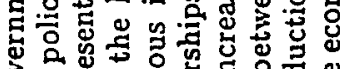

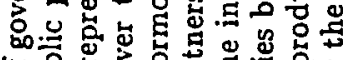

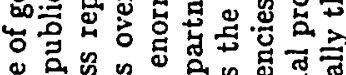

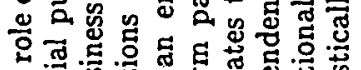

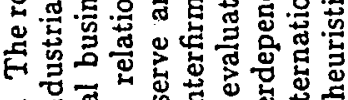

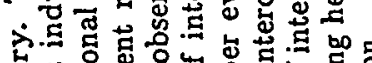

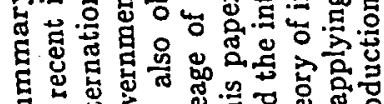

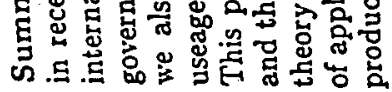

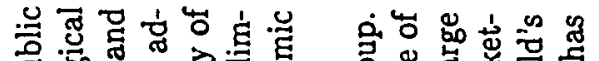

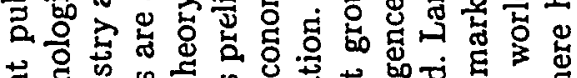

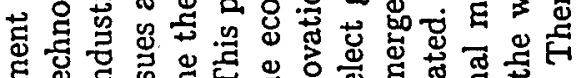

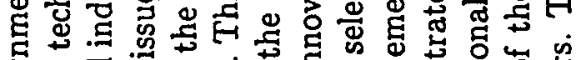

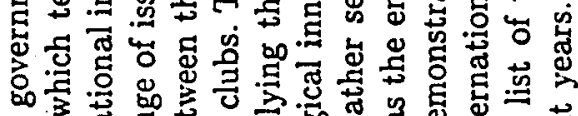
虫

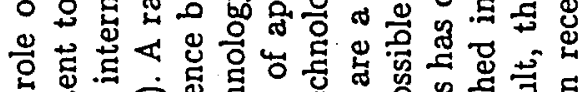

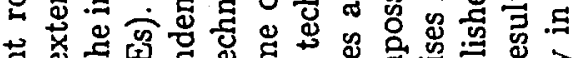

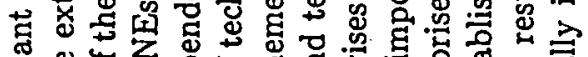

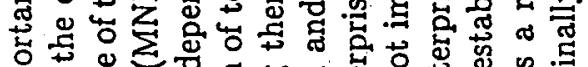

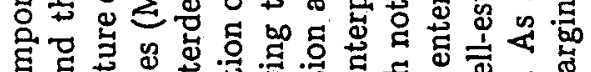

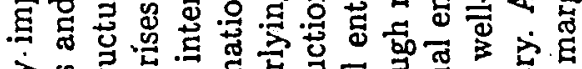

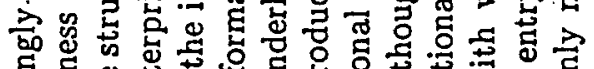

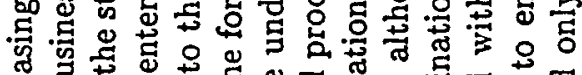

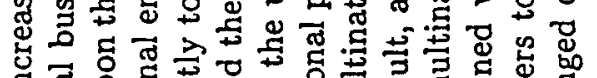

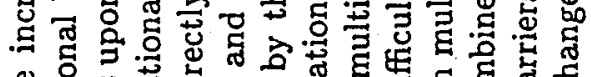

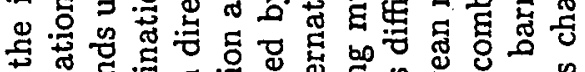

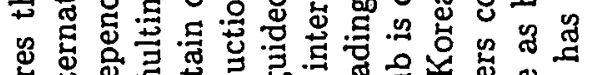

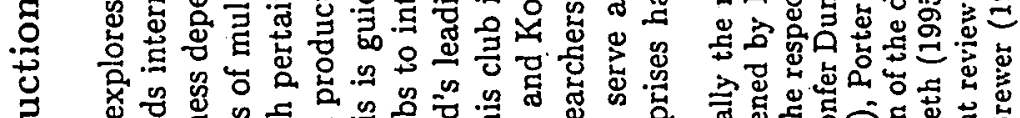

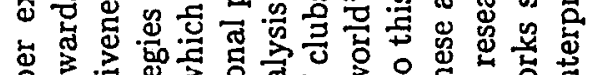

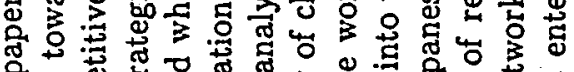

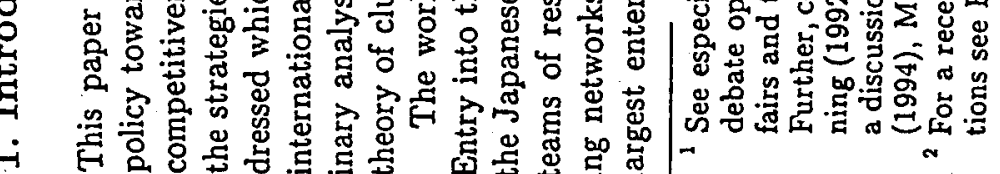

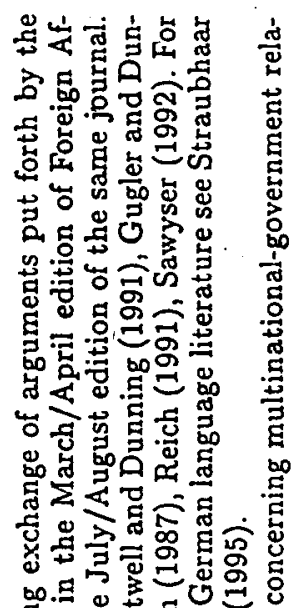

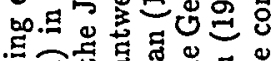

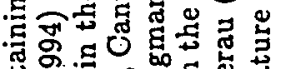

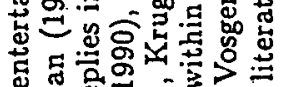

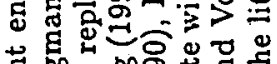

药

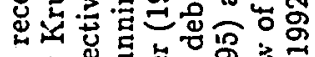

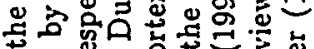

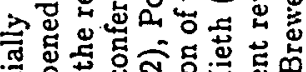

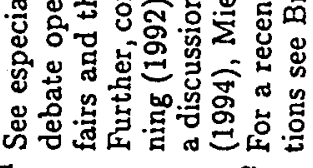
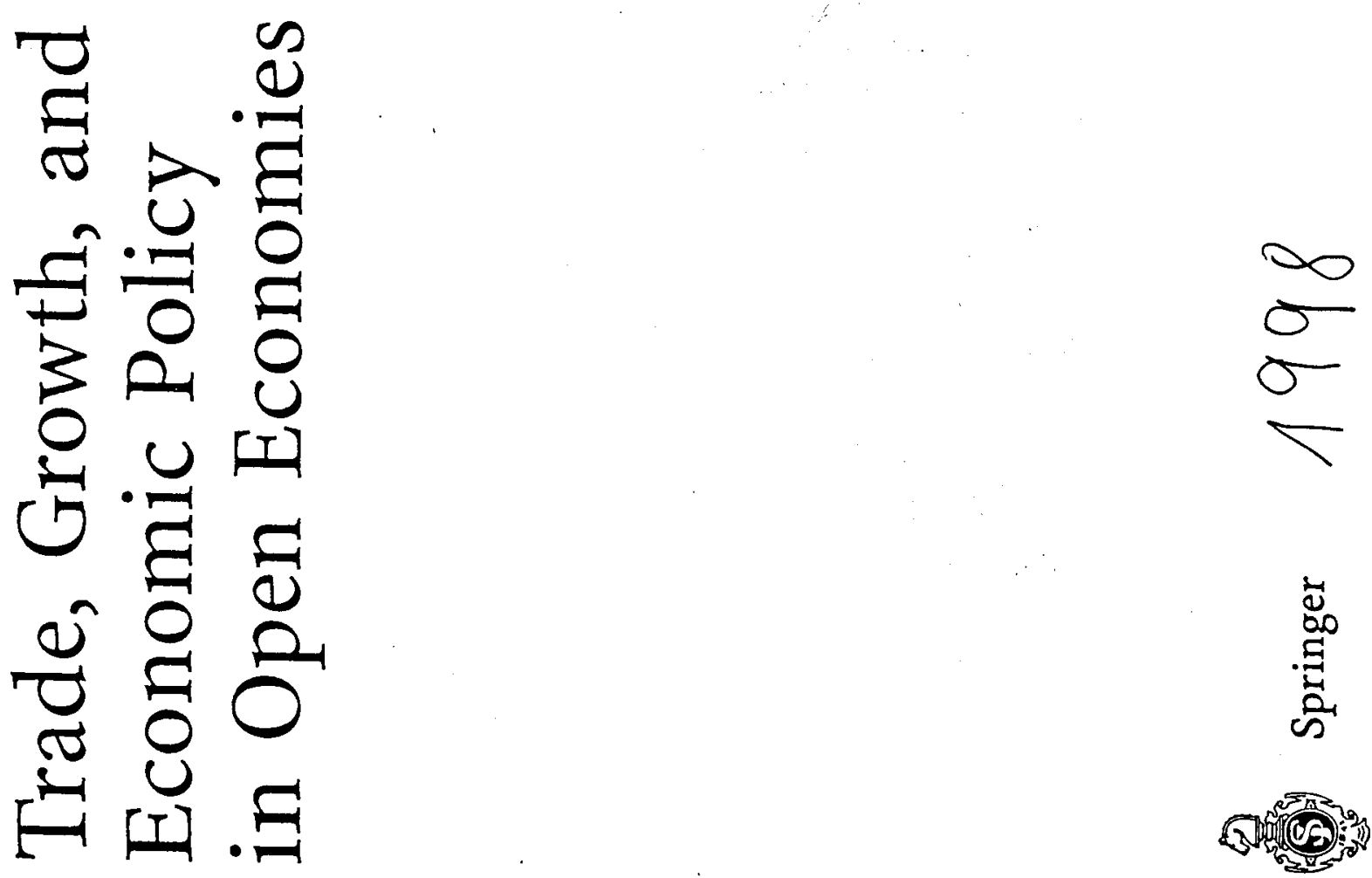


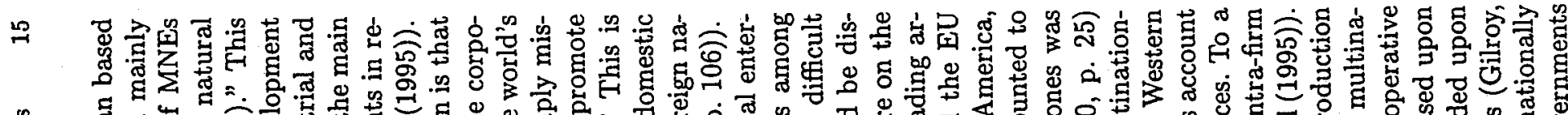

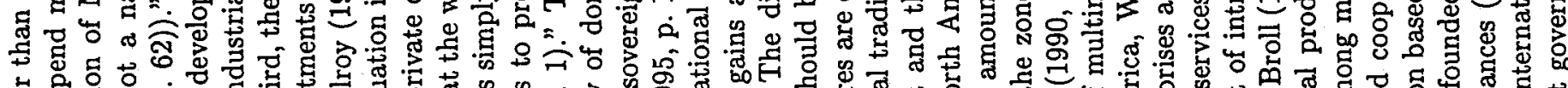

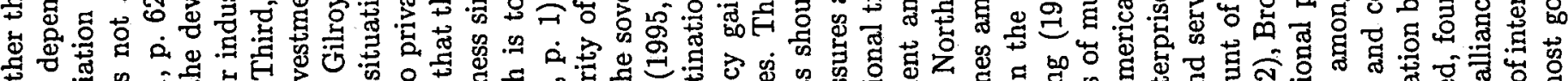

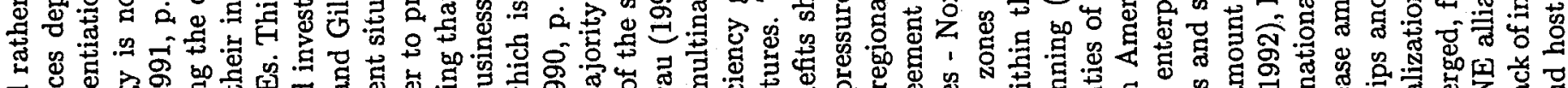

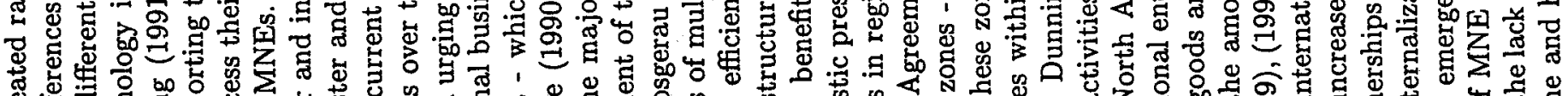

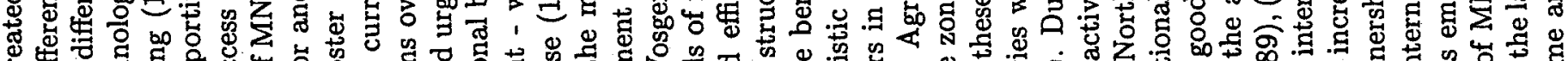

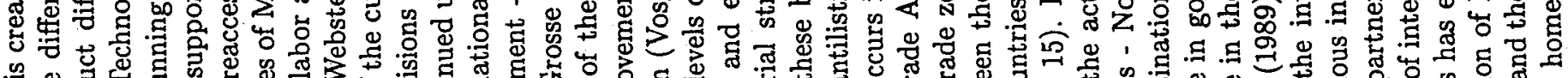
.

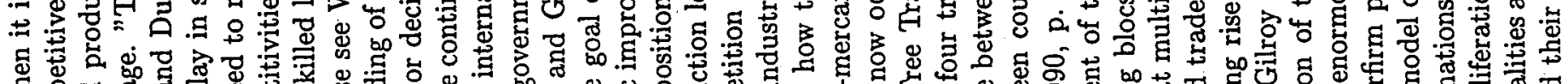

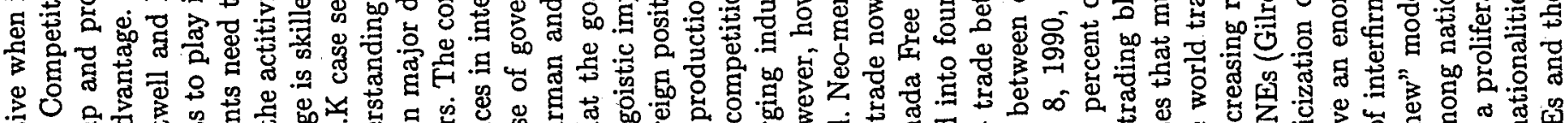

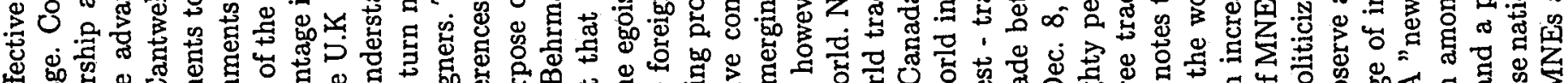

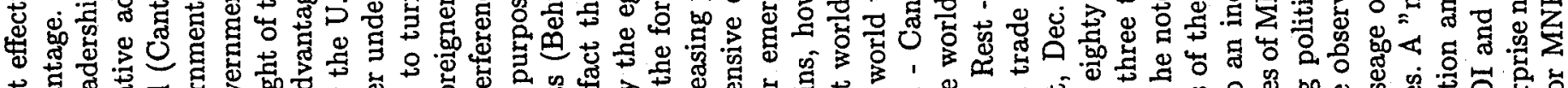

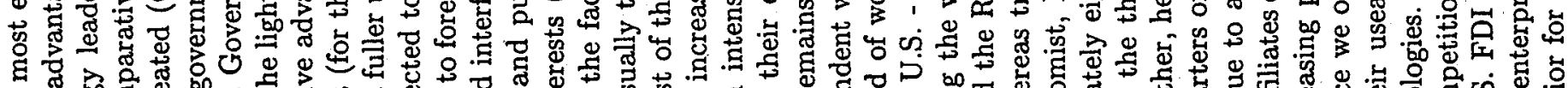

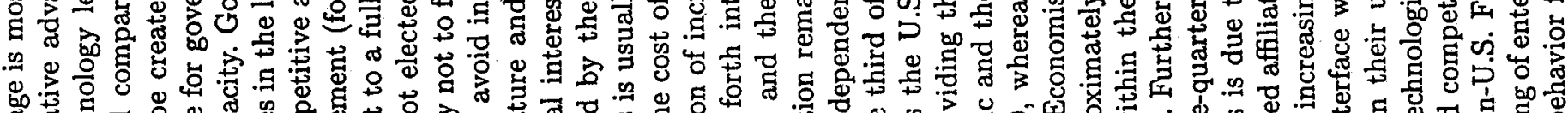

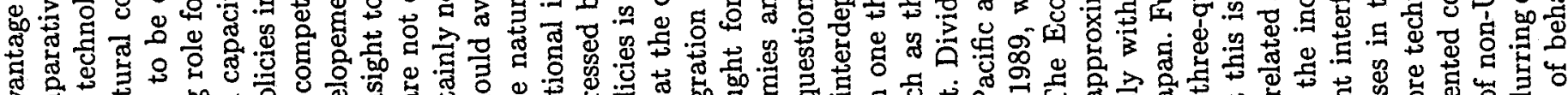

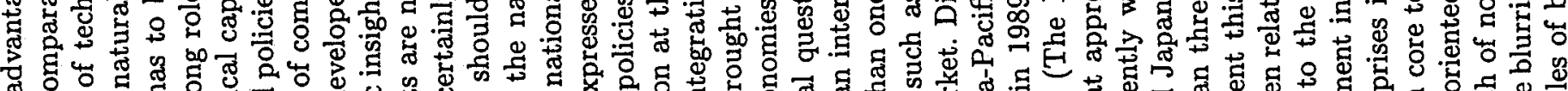

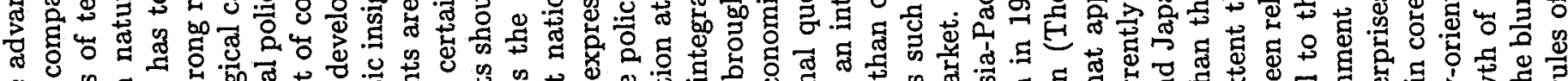

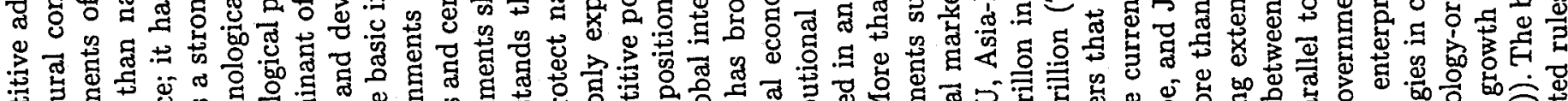

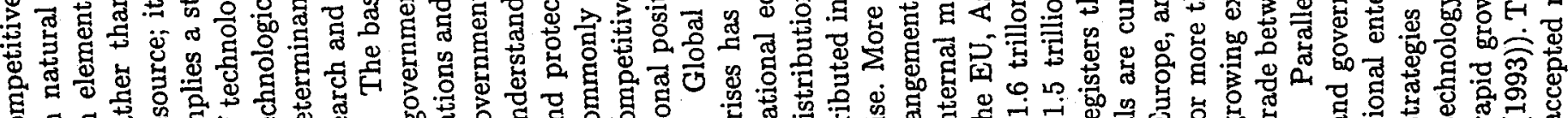

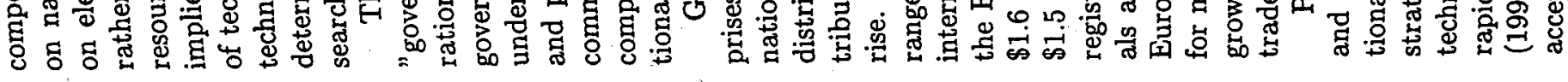

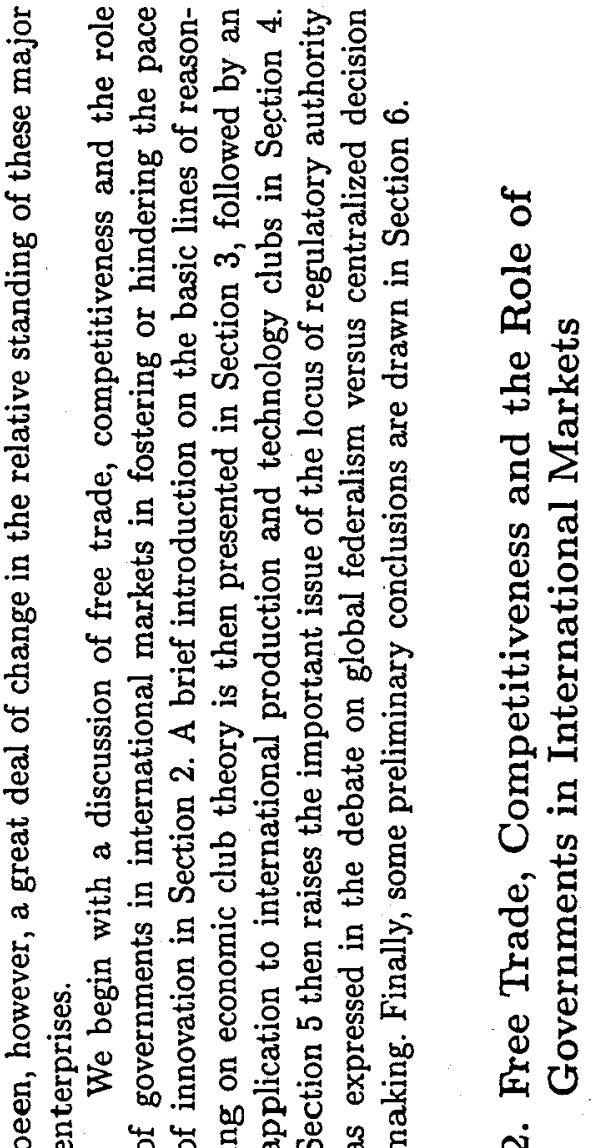

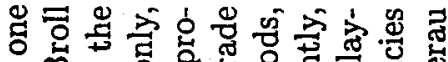

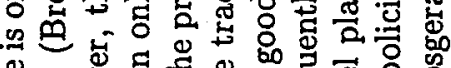

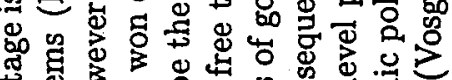

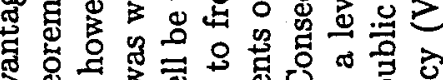

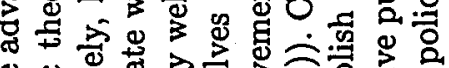

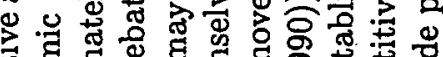

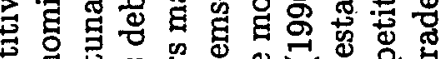

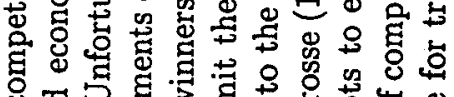

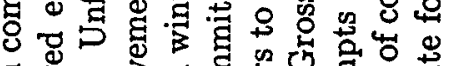

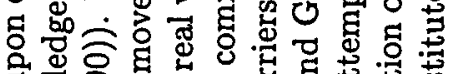

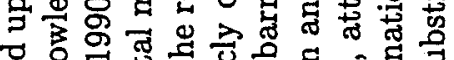

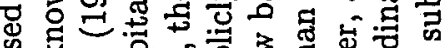

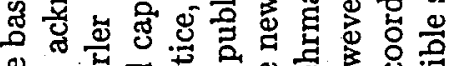

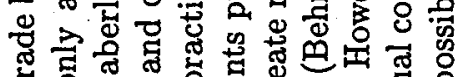

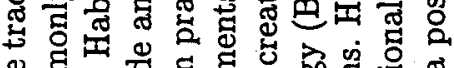
\& 世

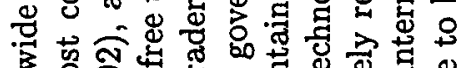

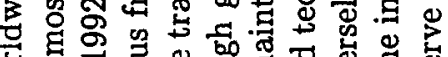

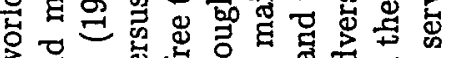

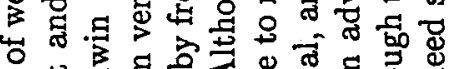

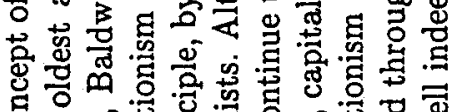

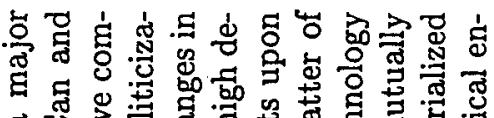
๙

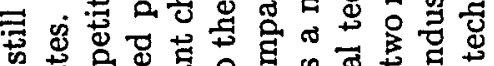

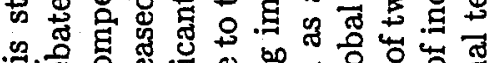
.

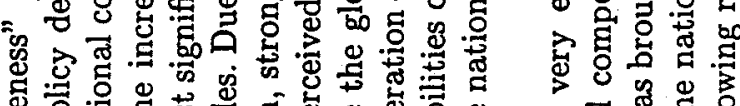

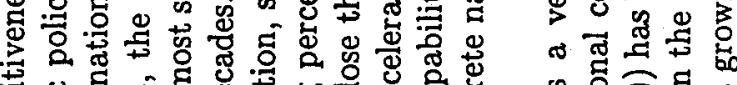

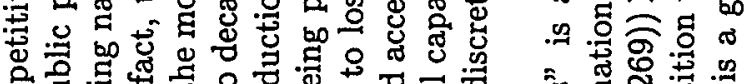

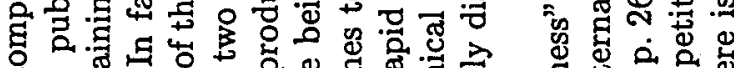

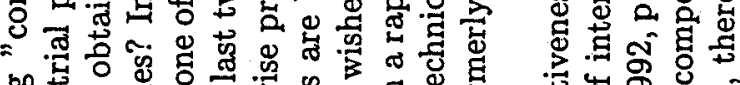

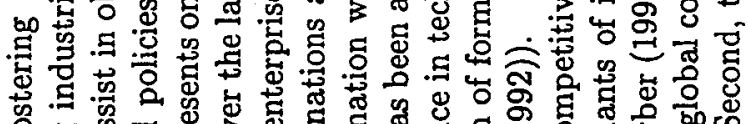
潒.

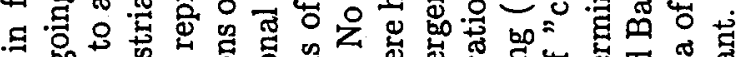

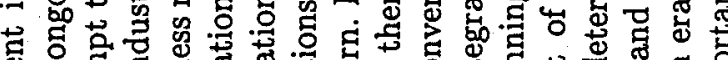

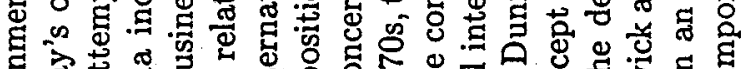

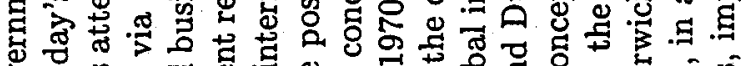

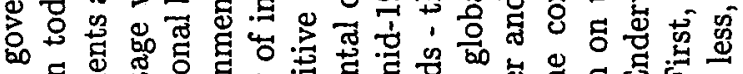

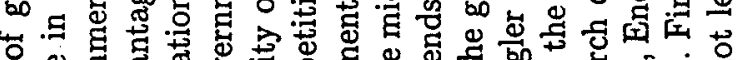

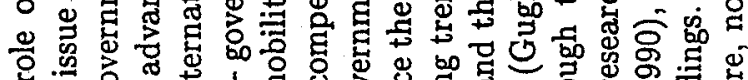
-

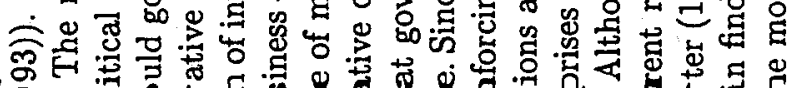

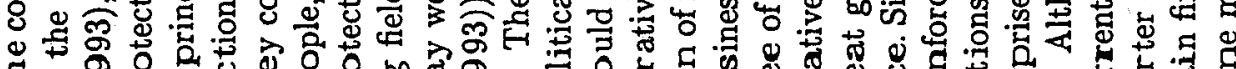

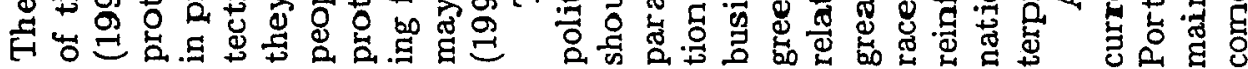




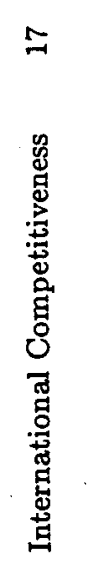

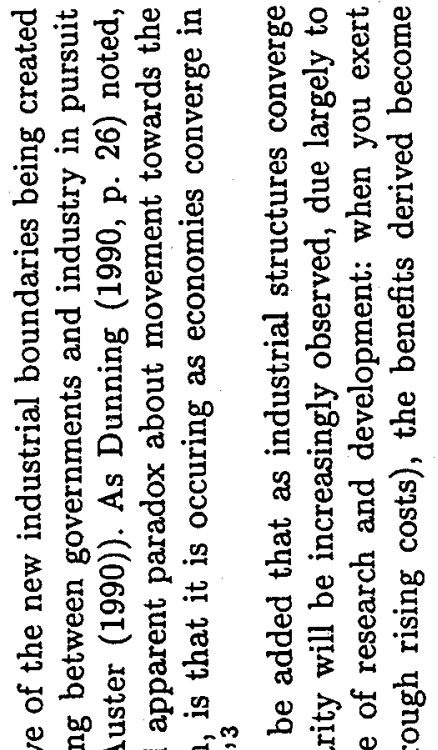

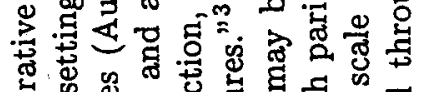
ज्ञ

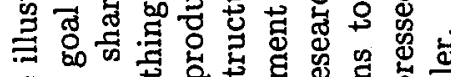

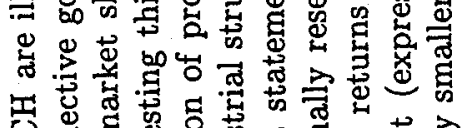

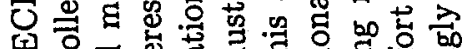

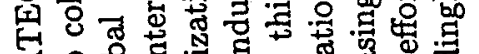

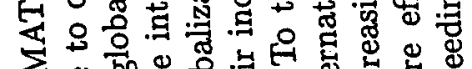

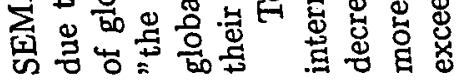

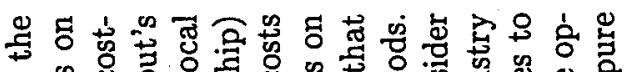

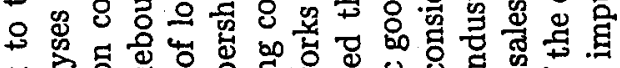

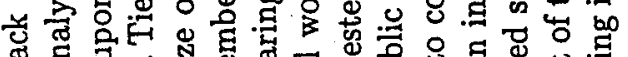

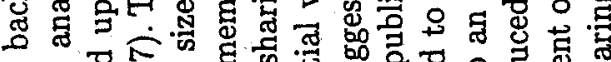

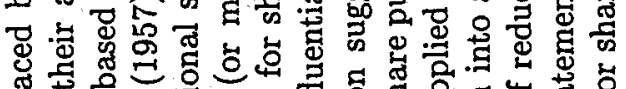

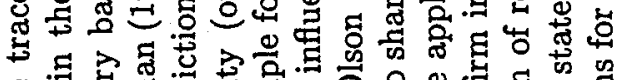

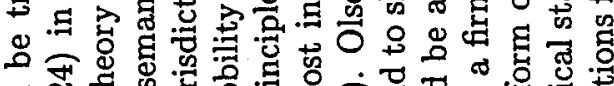

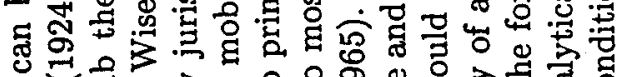

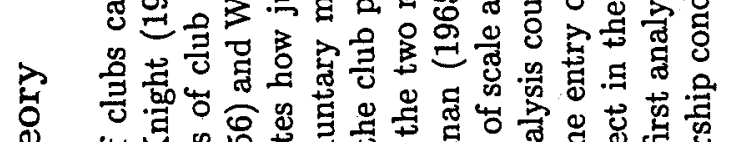

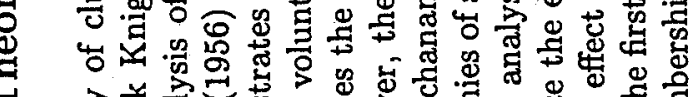

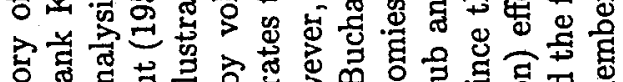

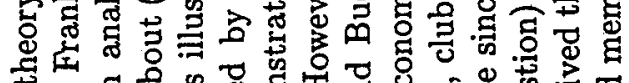

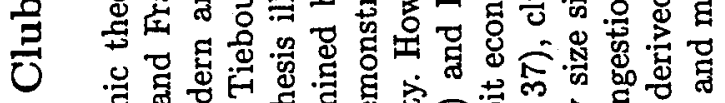
\$

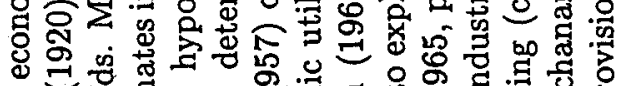

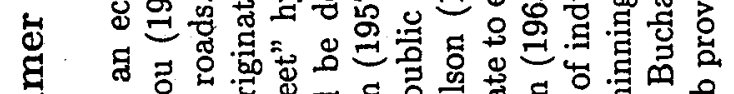
घ

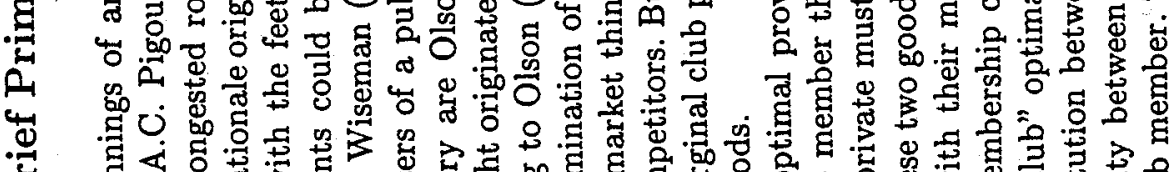

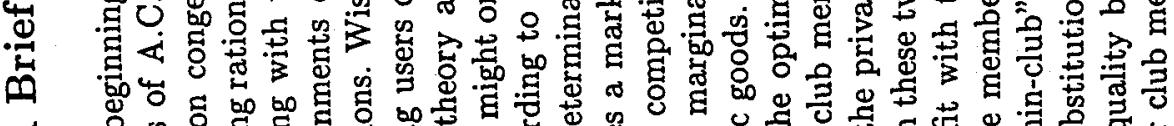

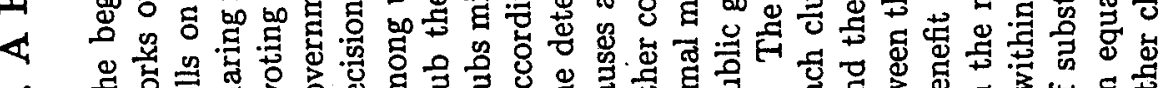
க

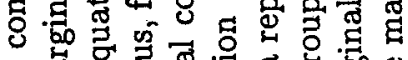

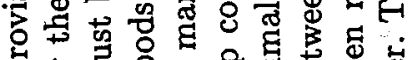

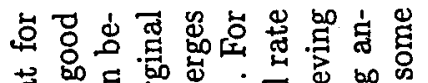

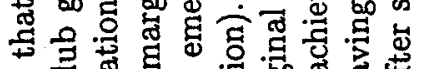

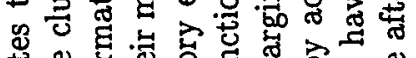

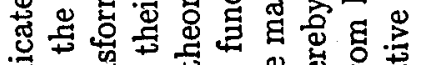

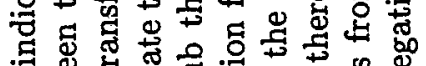

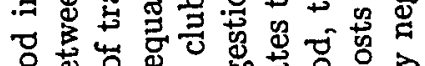

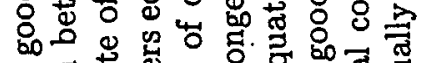

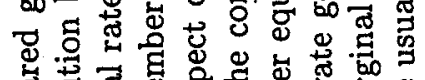

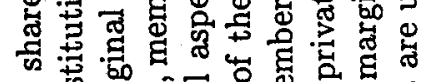

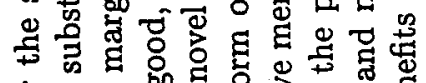

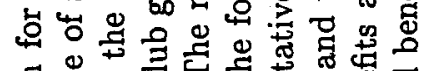

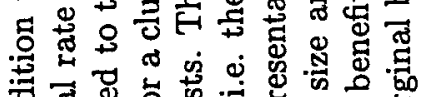

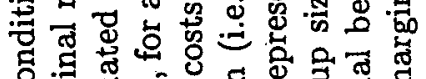

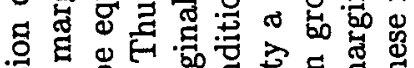
蛋

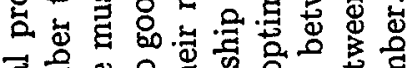
로ํํํำ 两 فํ. 突造 递 岁范

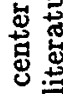
현 환 तै สำ 害 몸 $\ddot{4}$ 要范

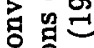
岁莺 동 突究

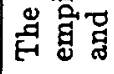

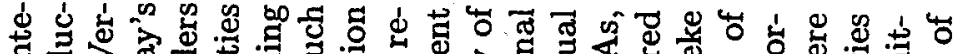

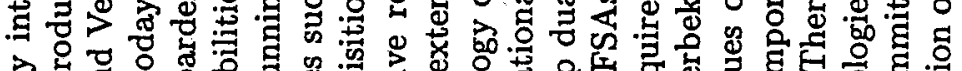

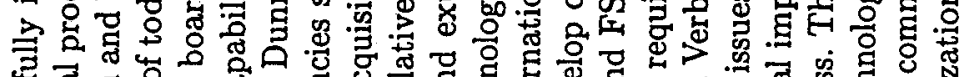

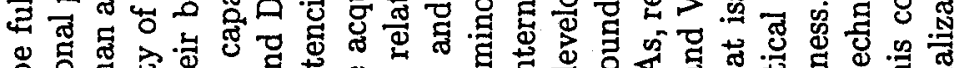

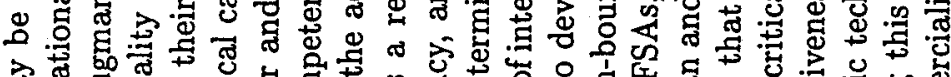

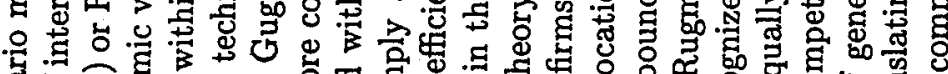

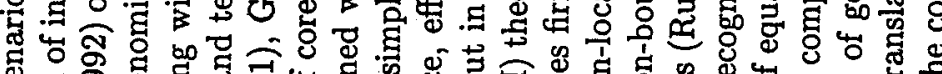

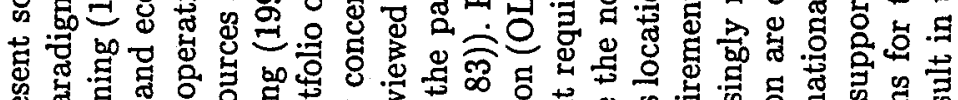

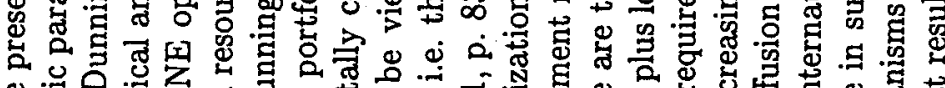

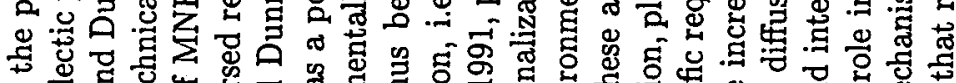

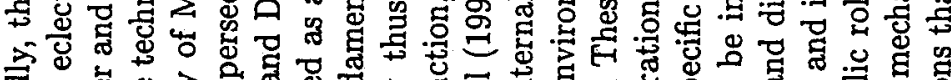

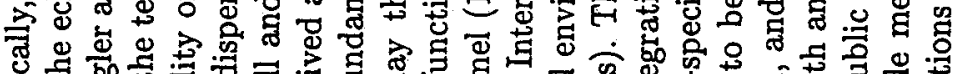

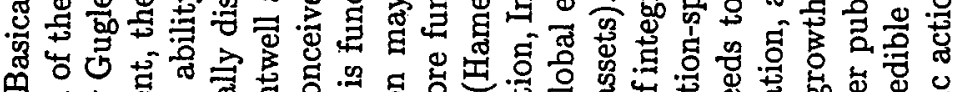

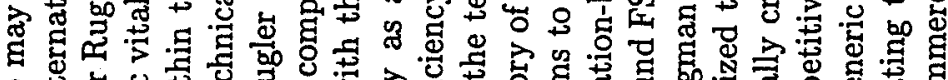

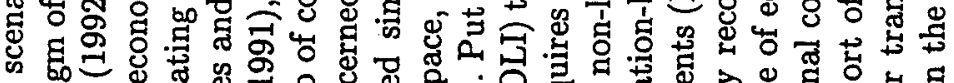

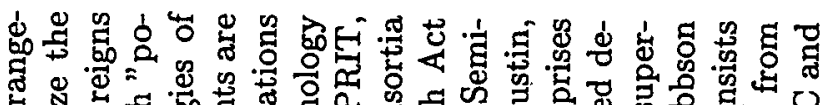

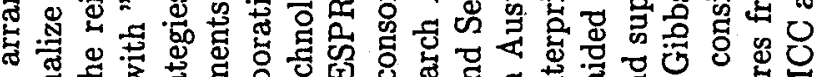

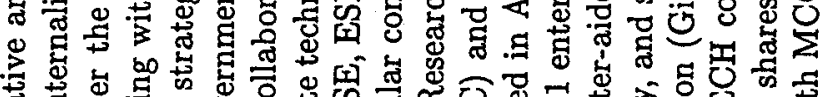

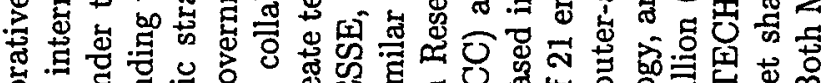

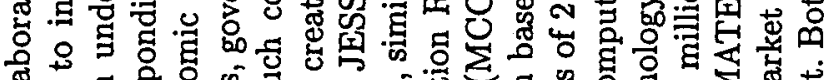
要

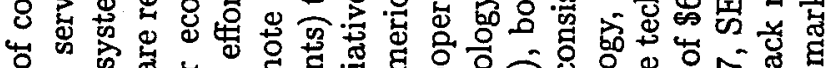

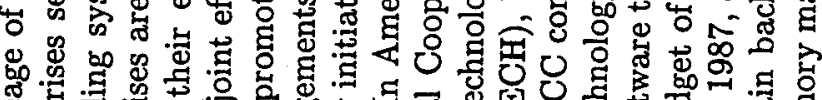

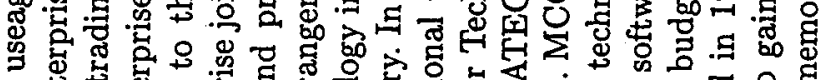

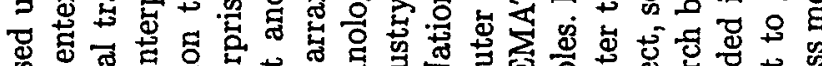

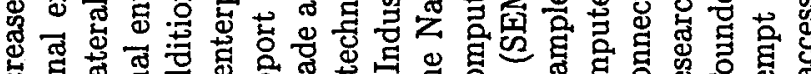

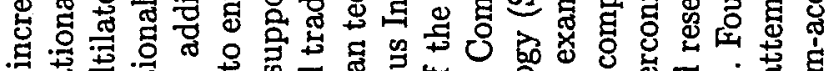

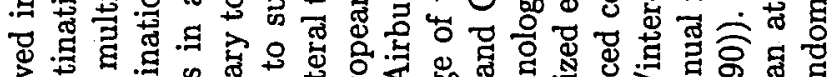

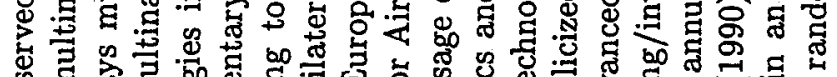

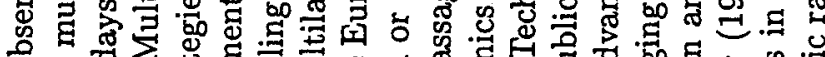

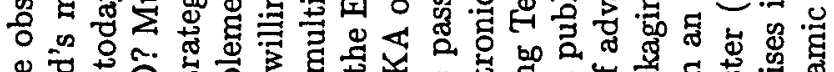

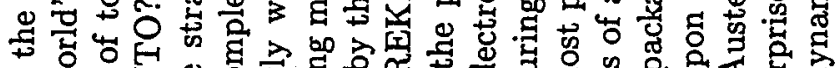

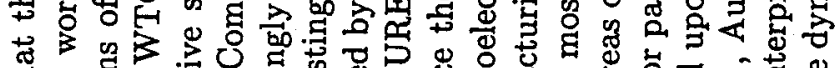

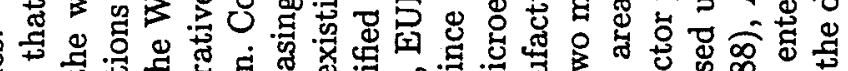

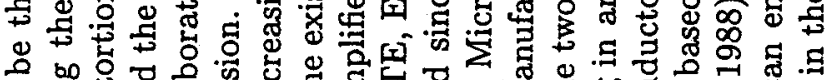

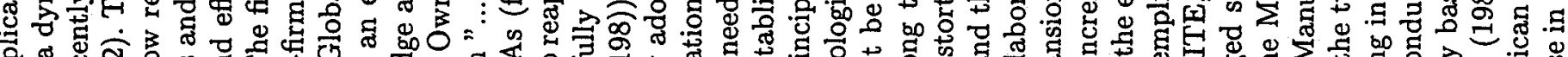

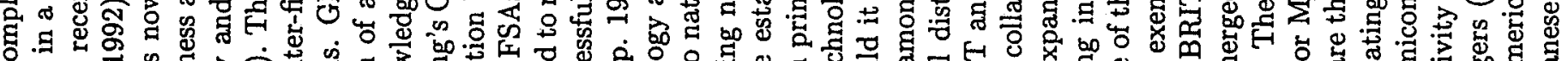

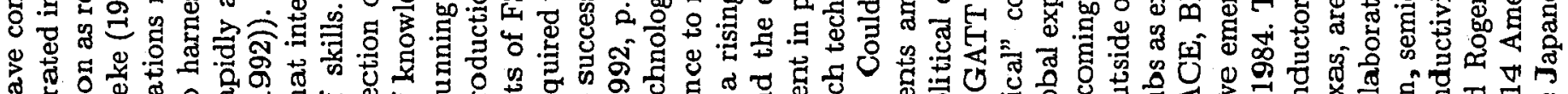

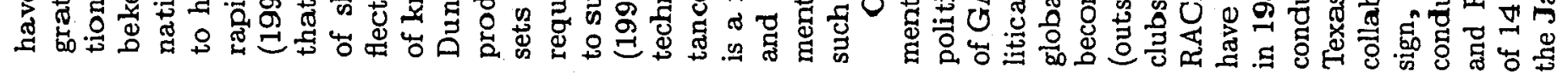




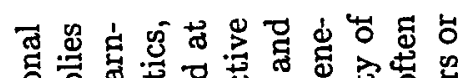

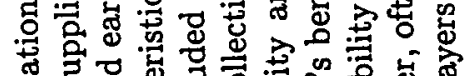

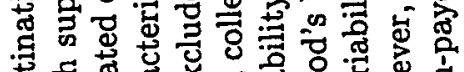

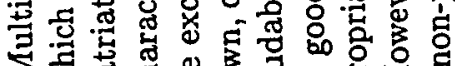

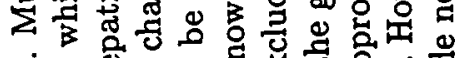
.

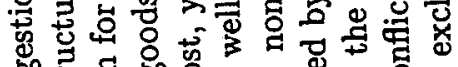

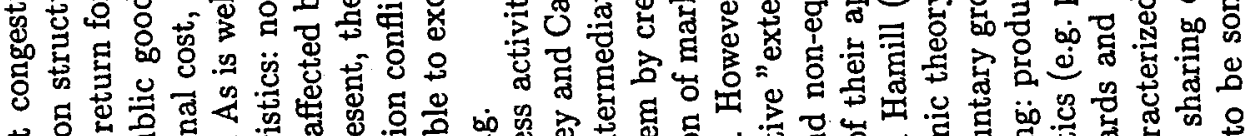

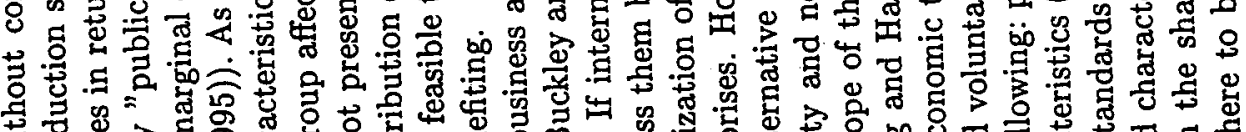

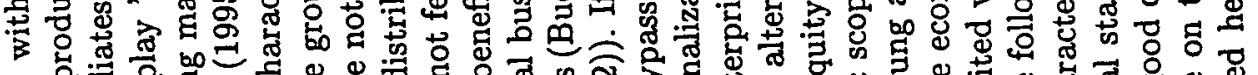

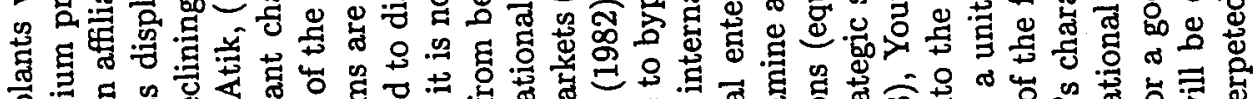

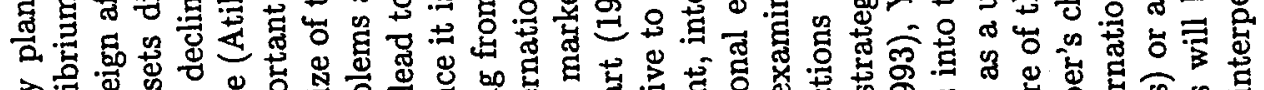

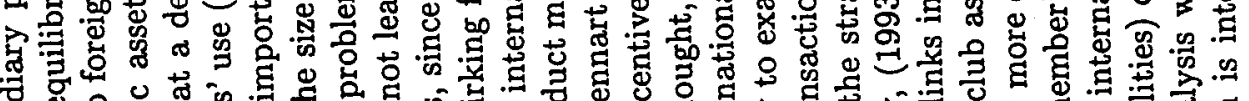

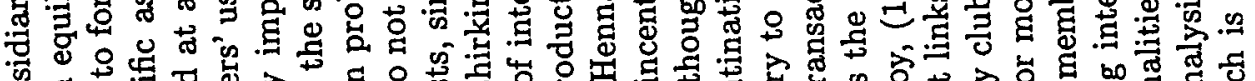

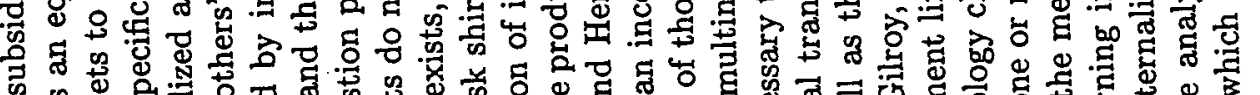
क

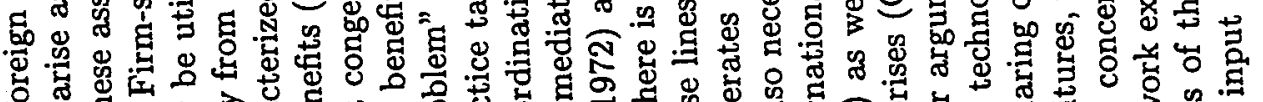

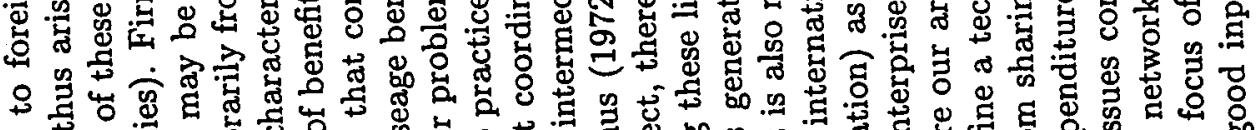

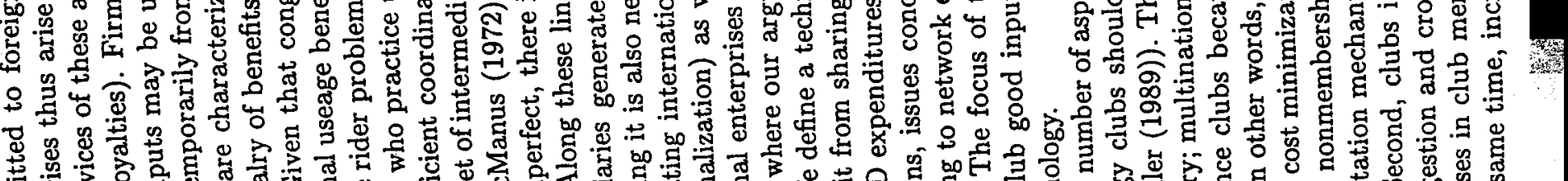

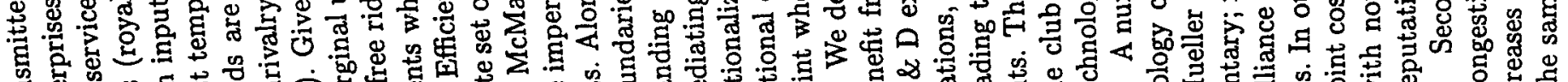

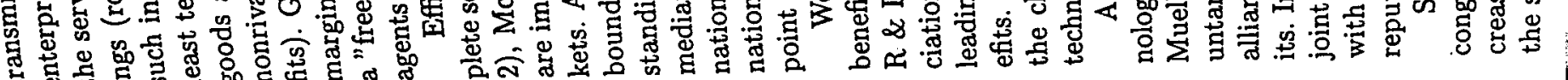

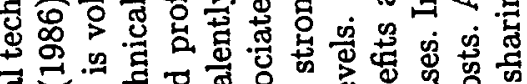

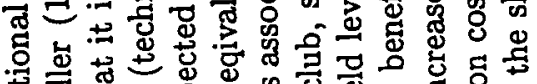

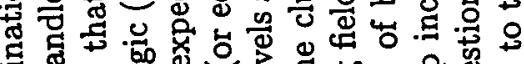
ஸึ.

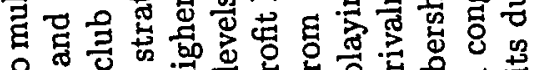
의

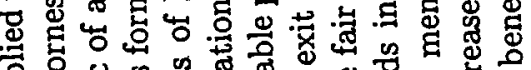

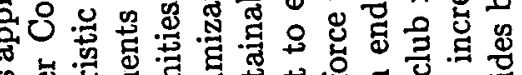

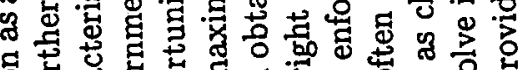

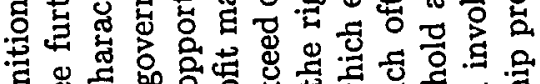

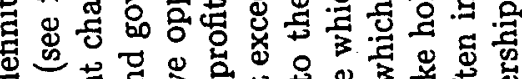

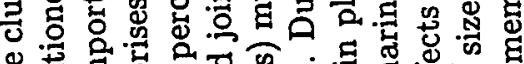

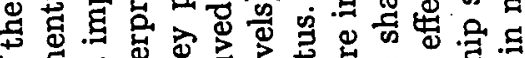

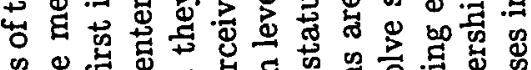
号告

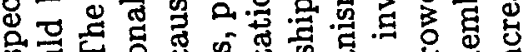
釷 .

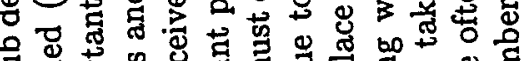

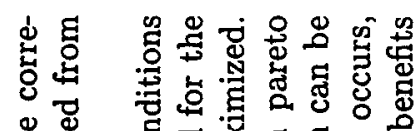

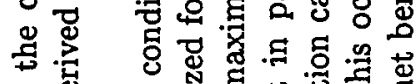

菏 음

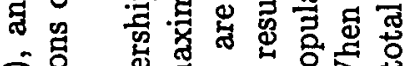

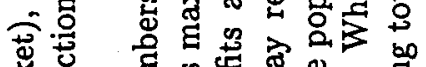

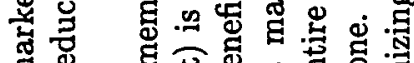

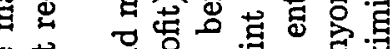

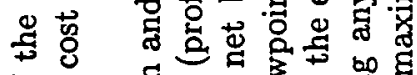

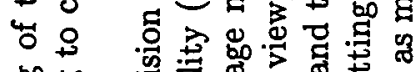

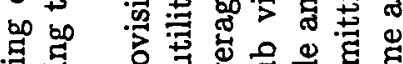

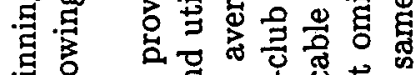

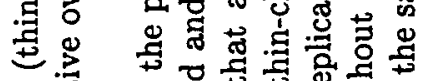

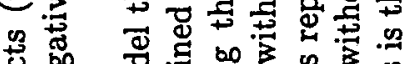

范边

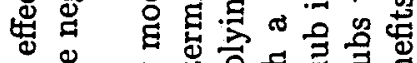

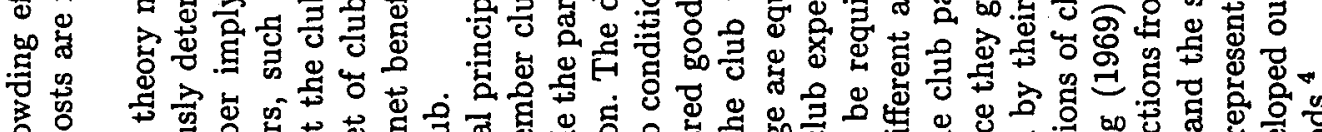

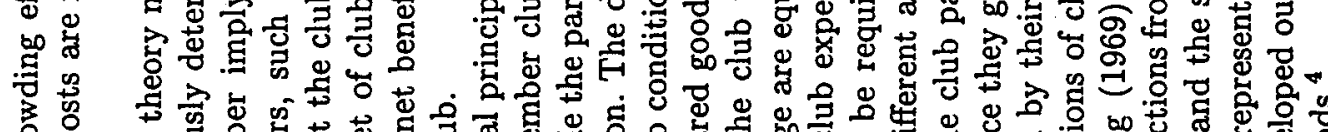

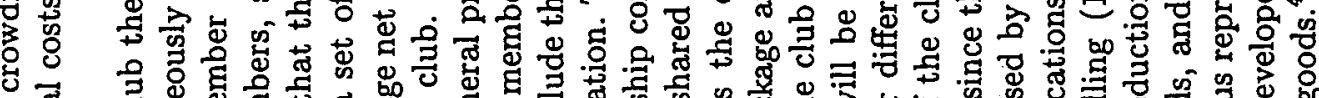

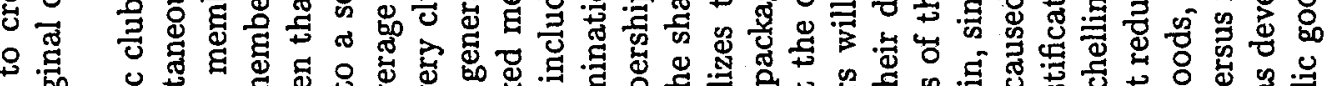

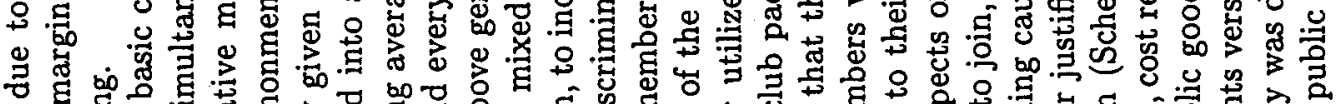

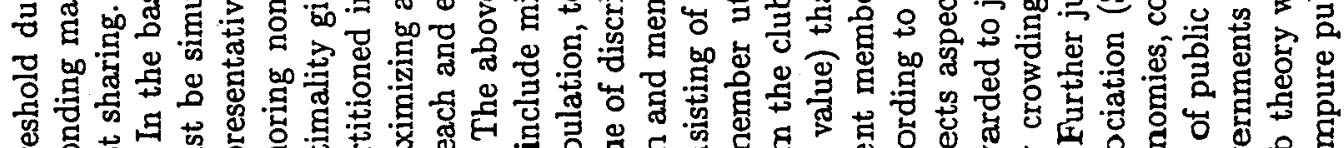

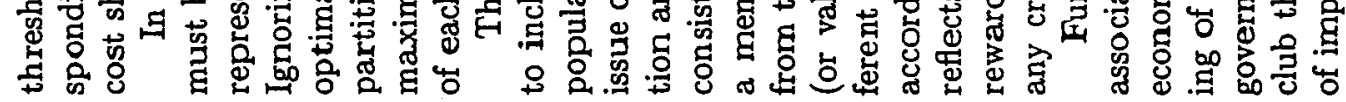


๘

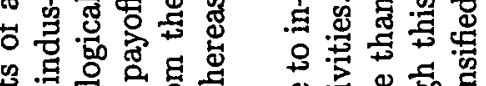

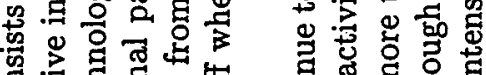

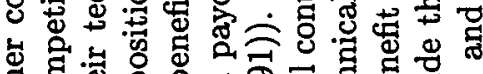
명영

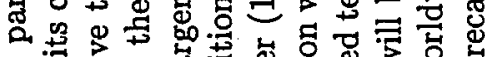

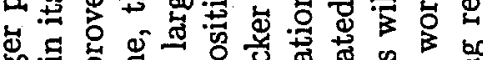

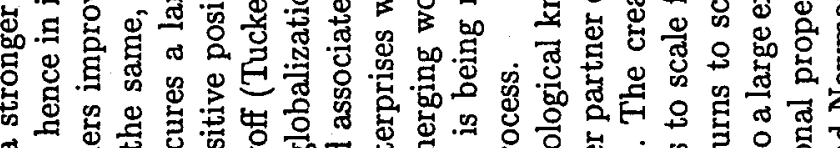

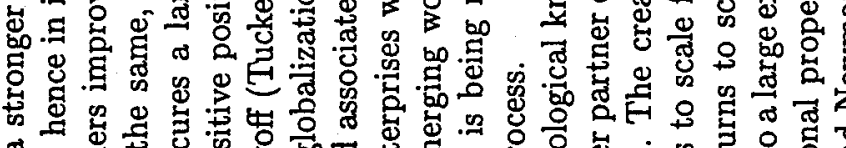

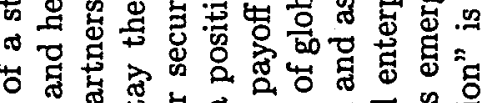

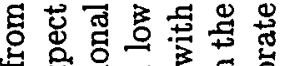

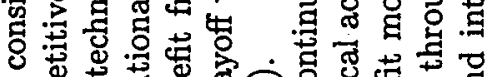

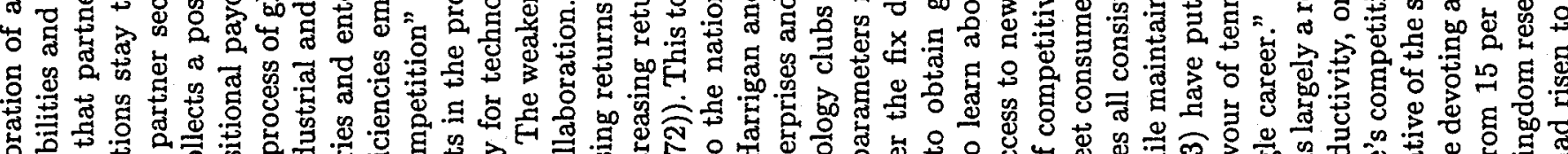
ช.

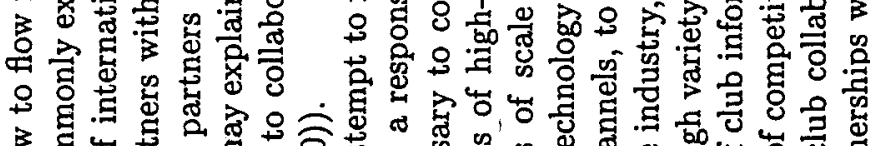
등

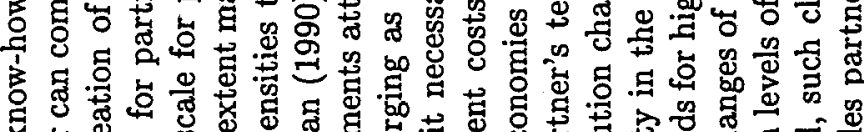

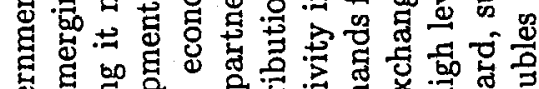
g.

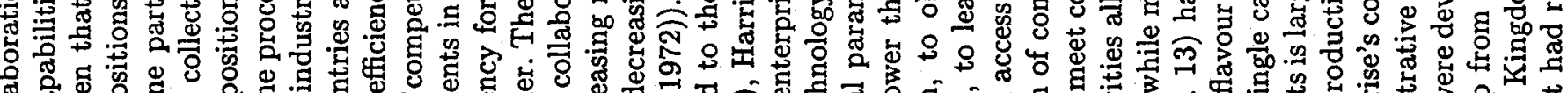

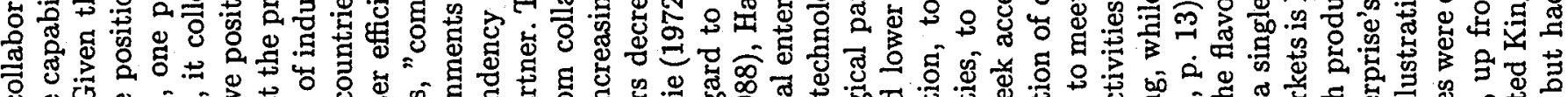

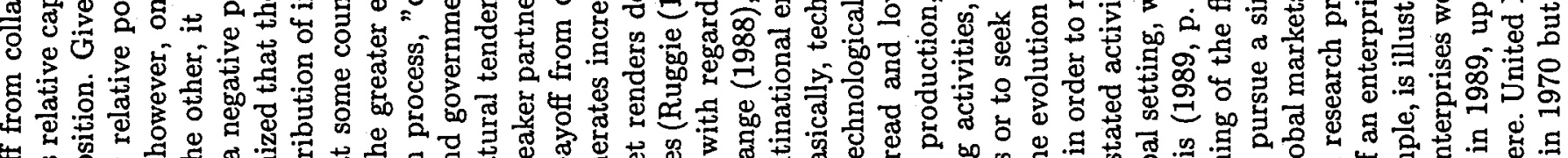

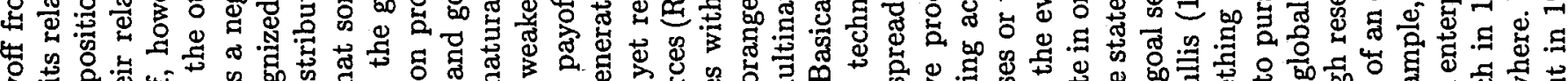

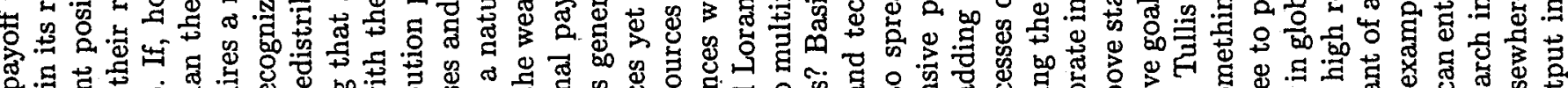

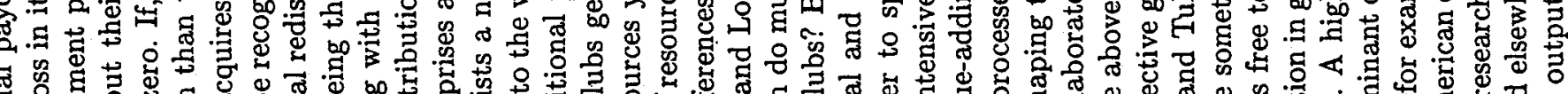

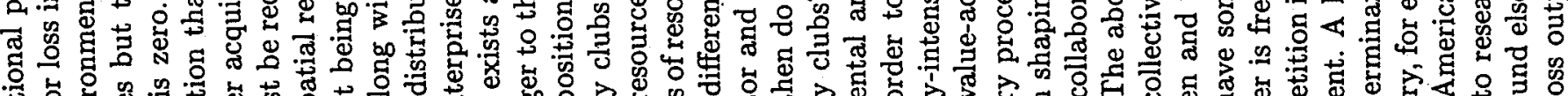

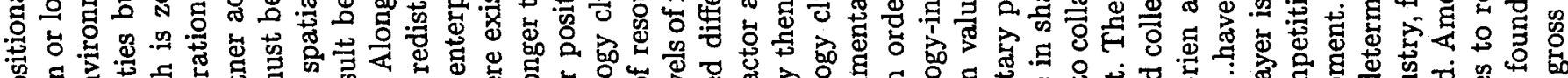

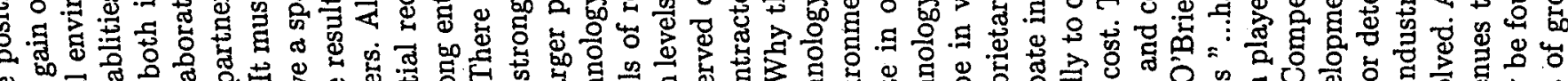

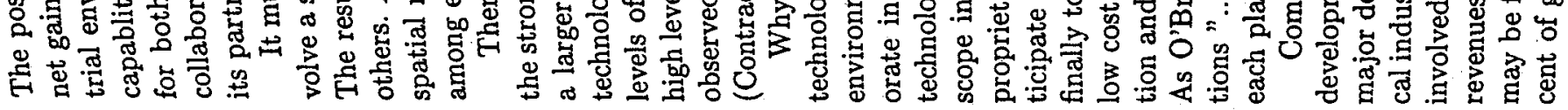

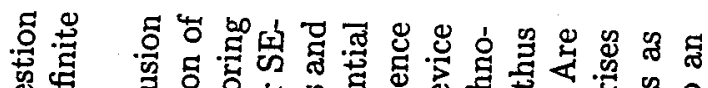
边

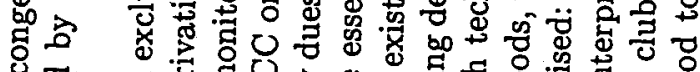

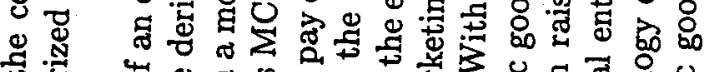

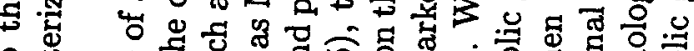

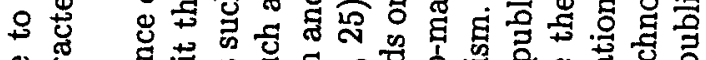

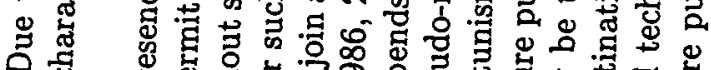
○

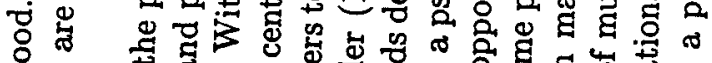
吵

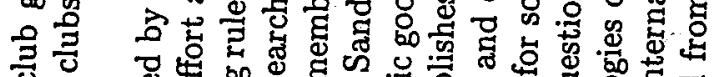
○ \&

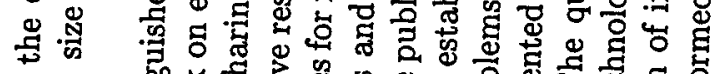

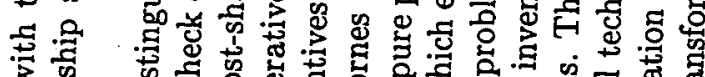

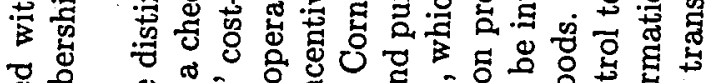

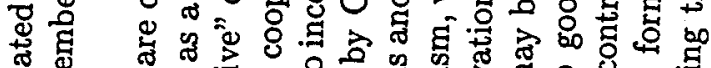

$\stackrel{\overparen{Z}}{\mathbb{E}}$

等

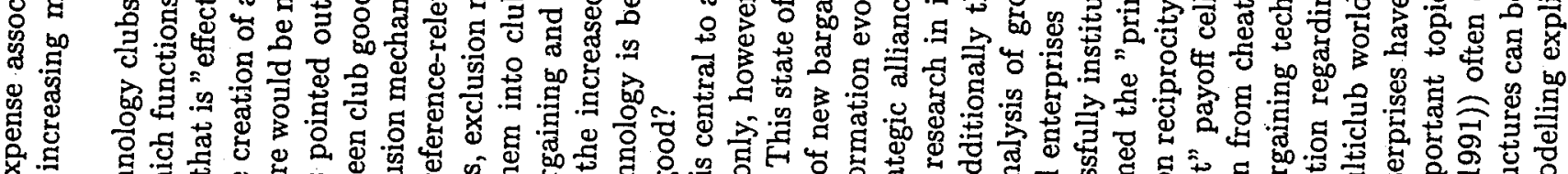

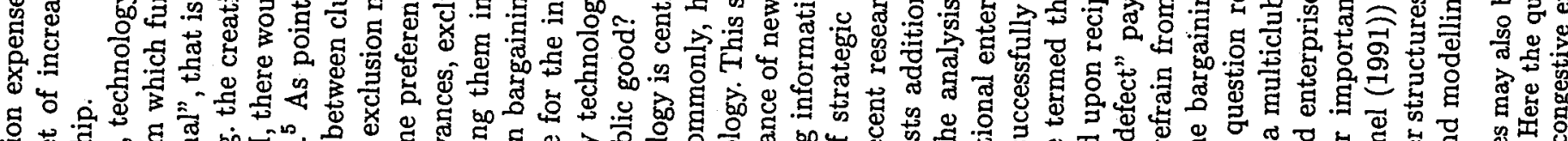

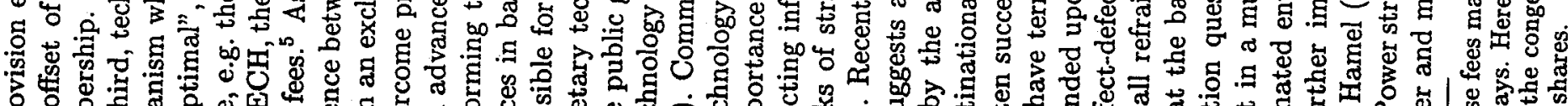
О.

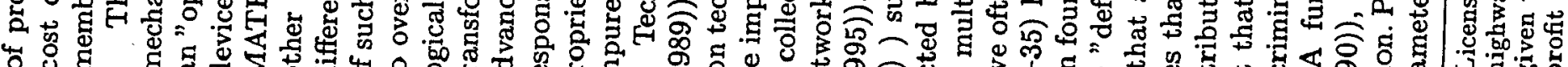

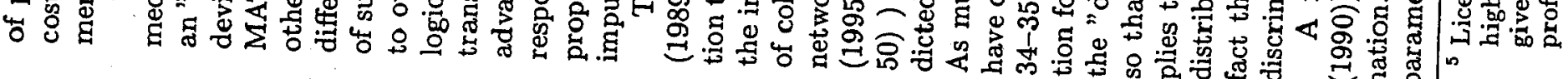




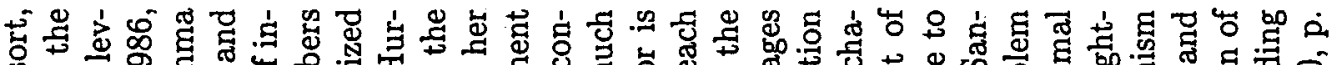

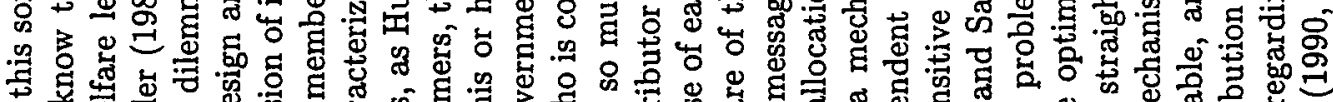

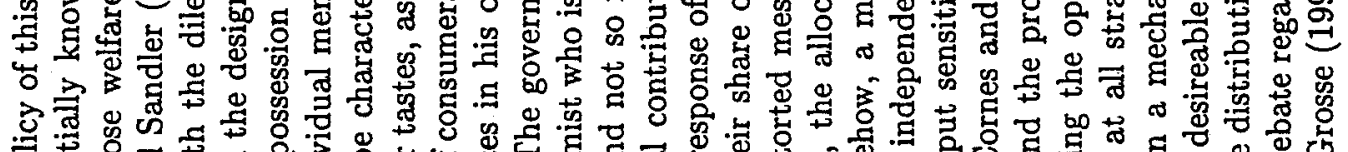

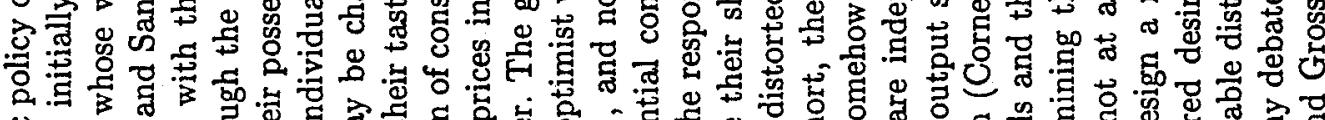

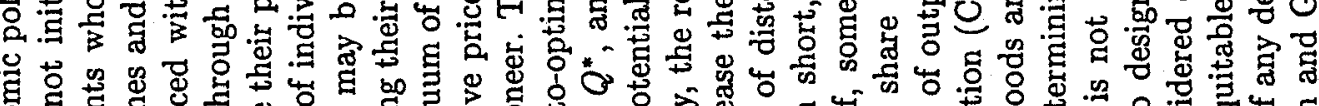

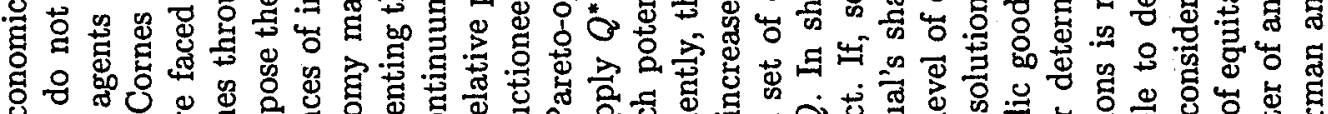

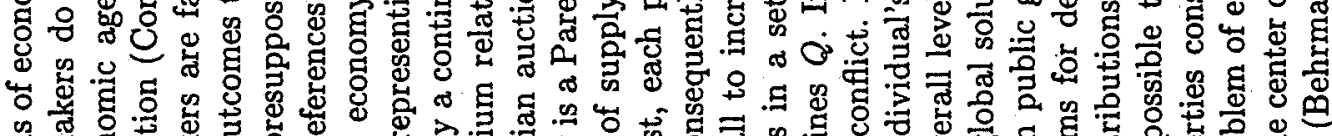

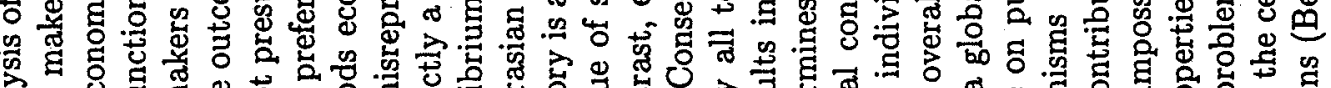

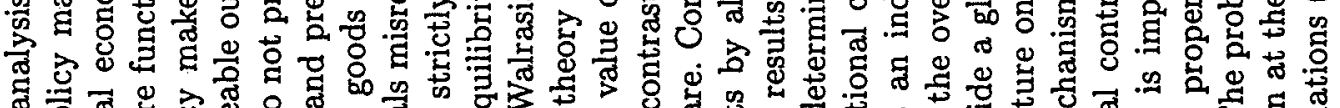

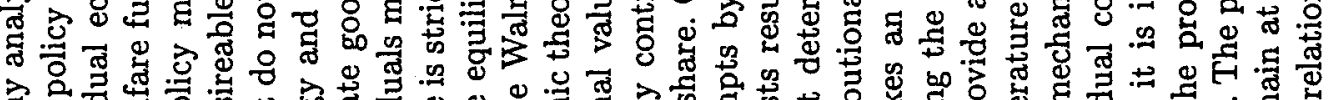

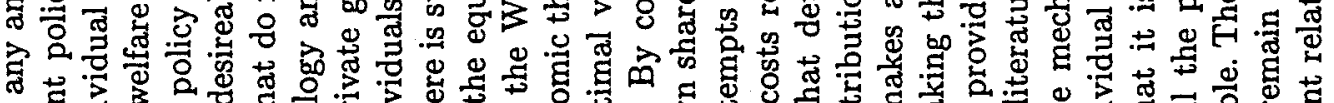

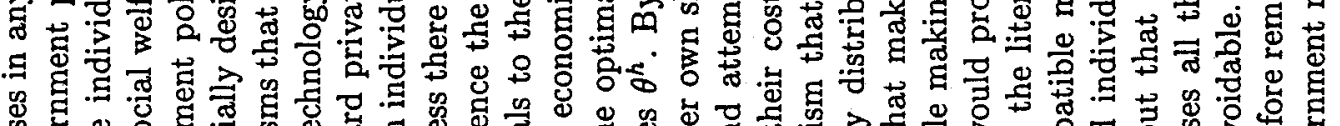

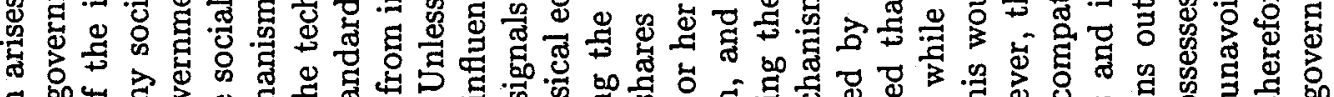

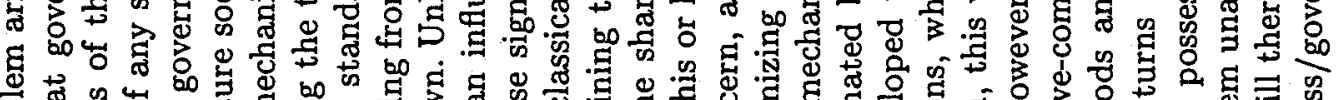

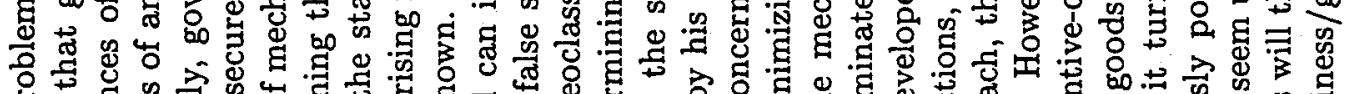
年

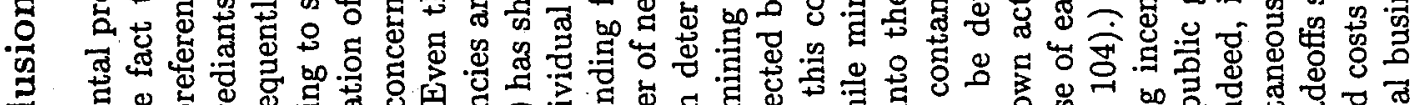

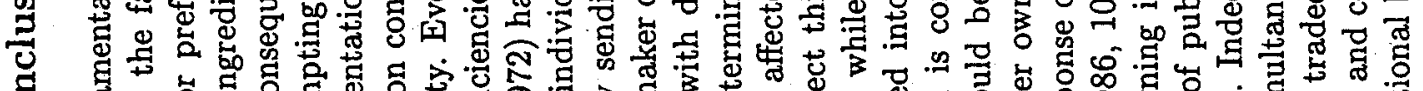

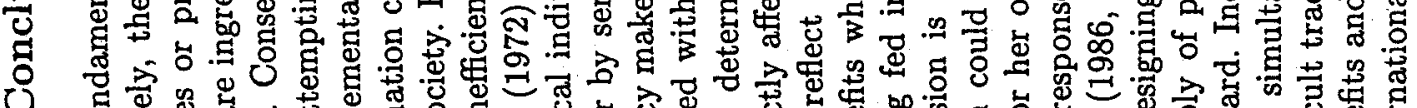

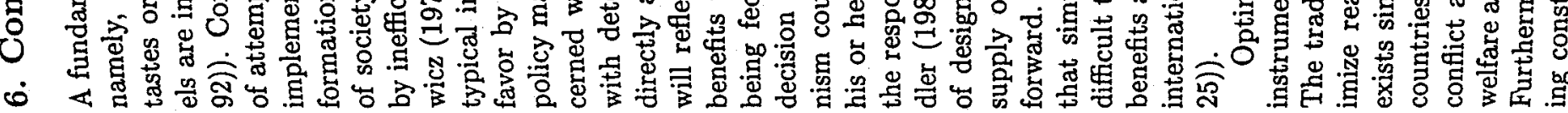

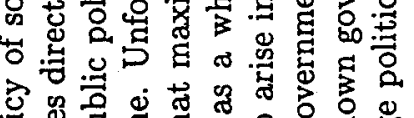

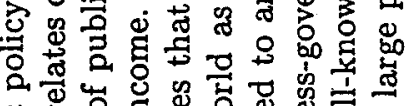

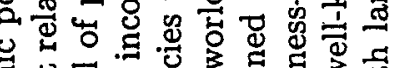

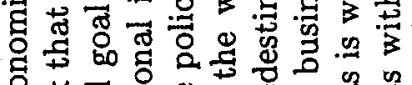

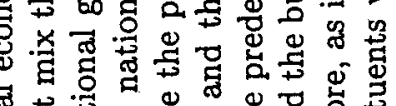

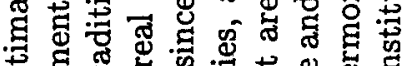

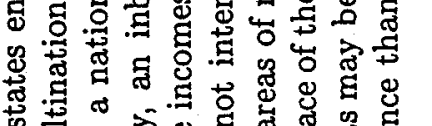

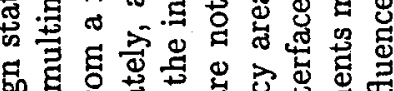

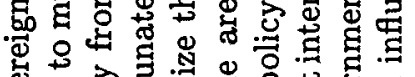

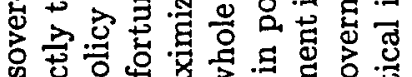

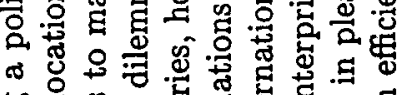

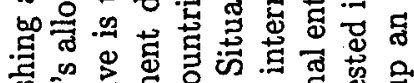

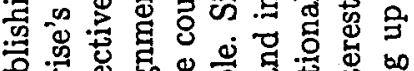

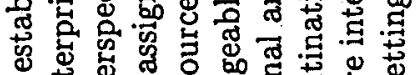

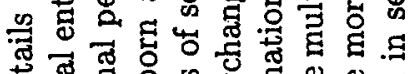

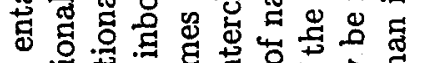

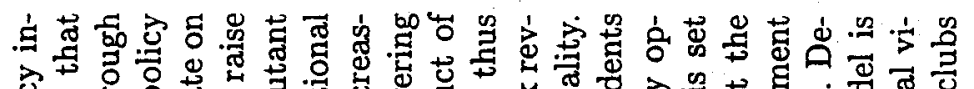

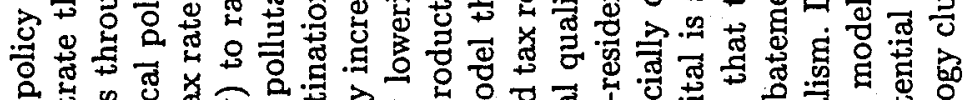

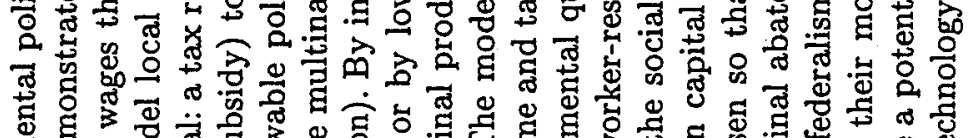

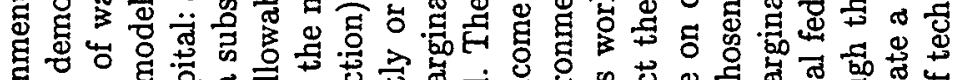

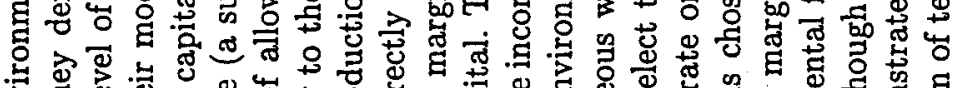

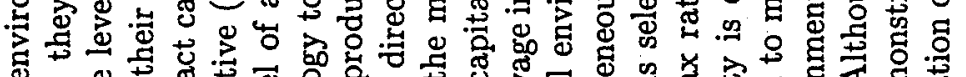

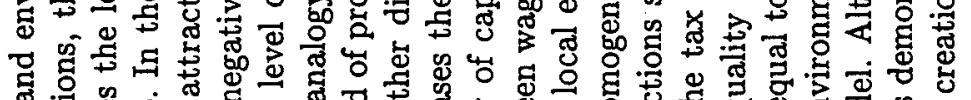

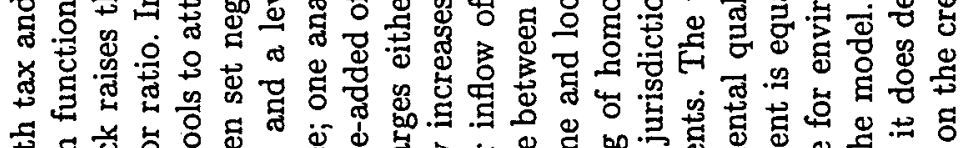

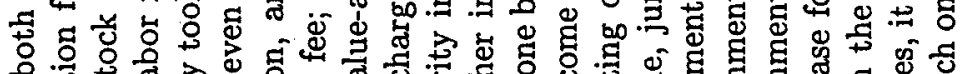

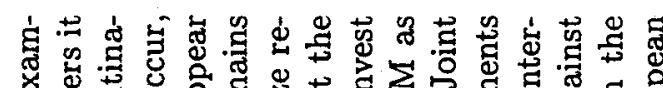

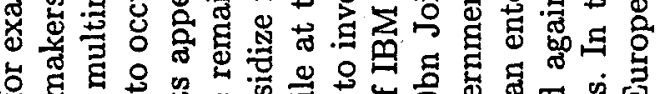

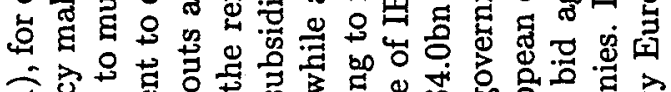

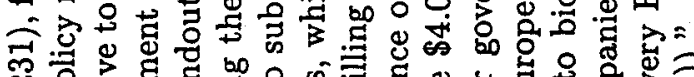

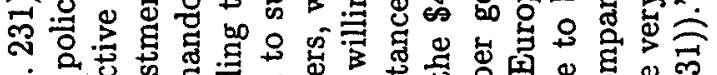

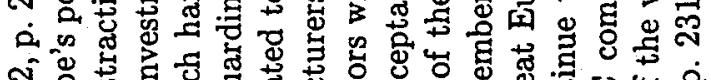

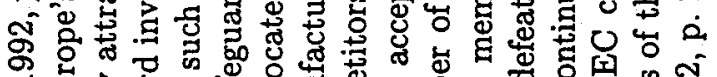

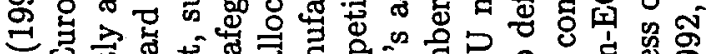

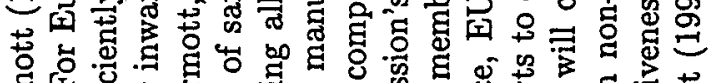

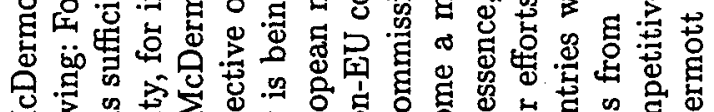

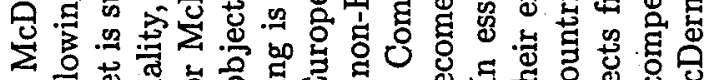

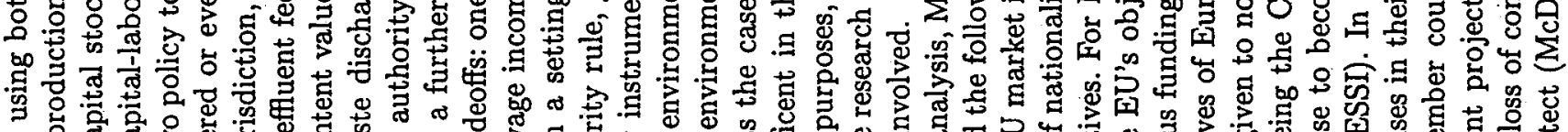

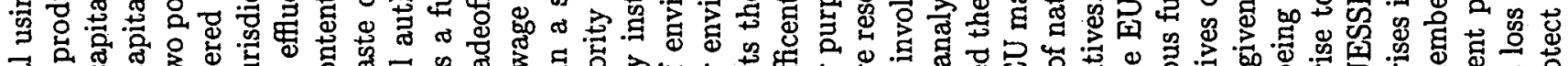

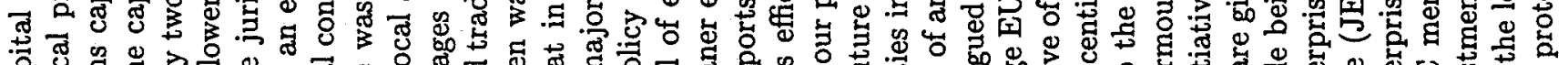

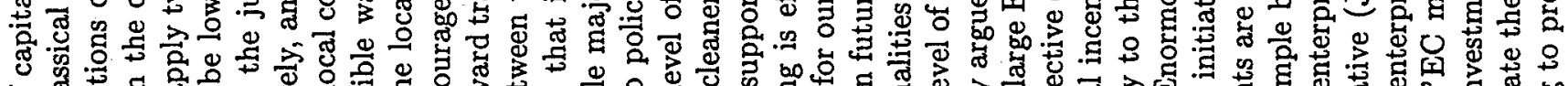

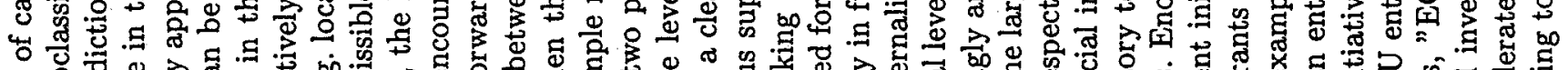
융.

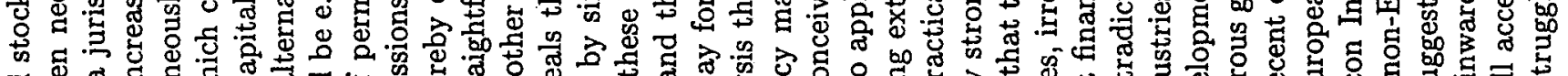
๙

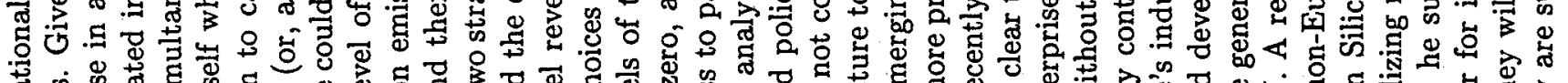

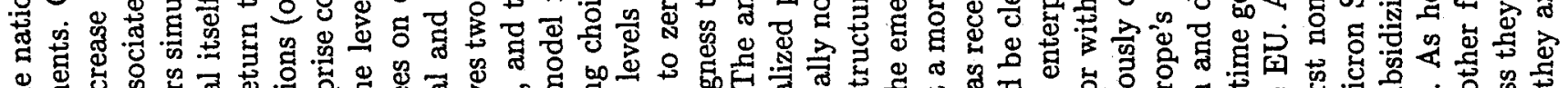

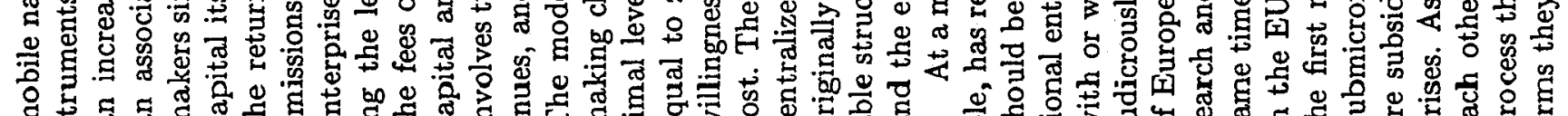




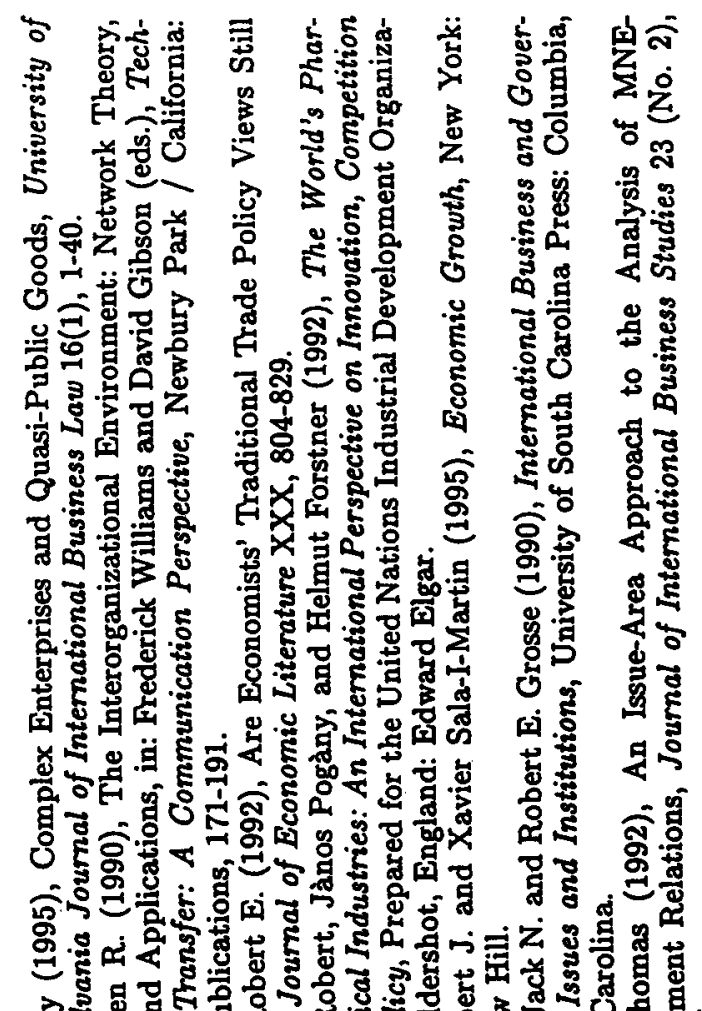

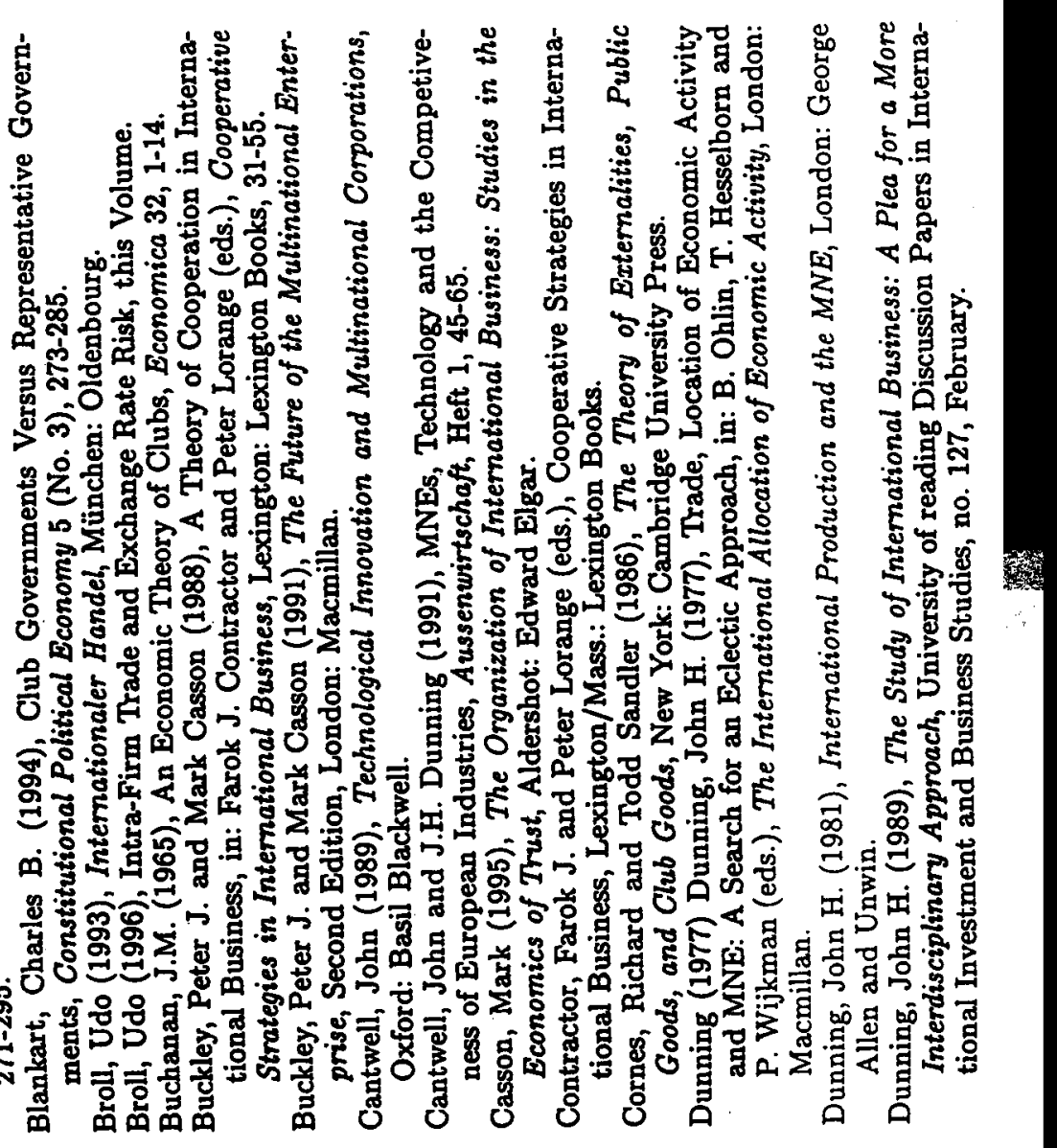

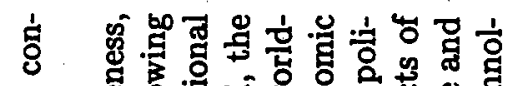

子

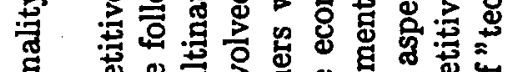

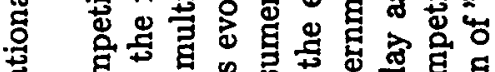

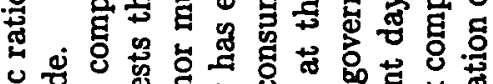

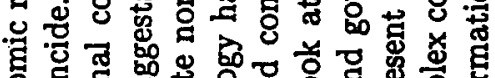

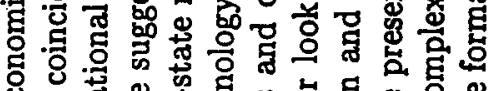
రัष

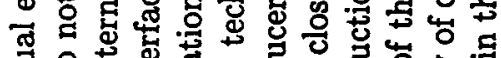

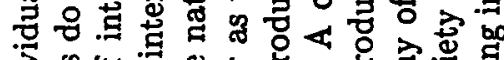

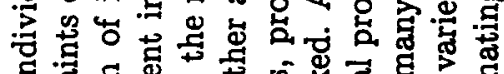
.

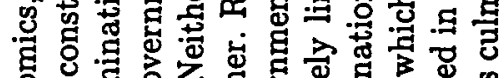

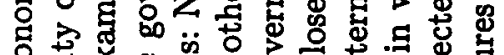

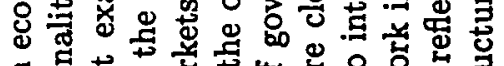
.

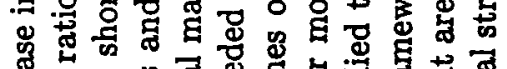

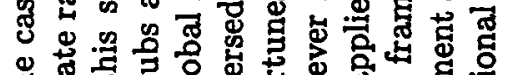

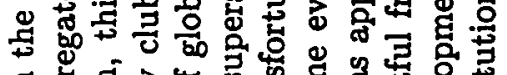

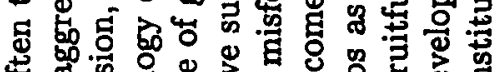

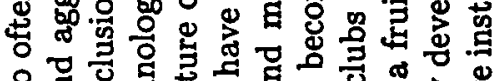

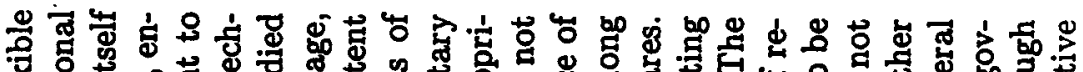

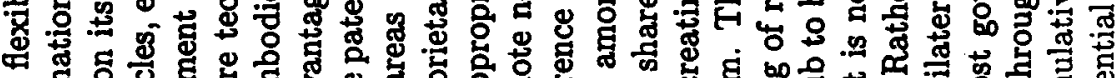

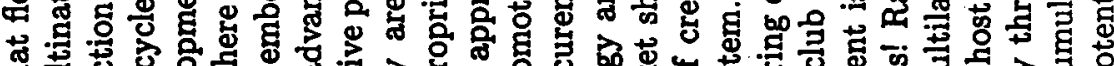

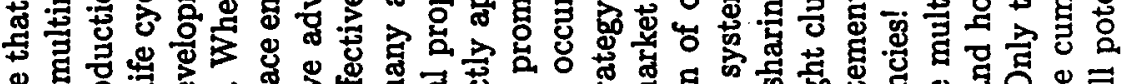

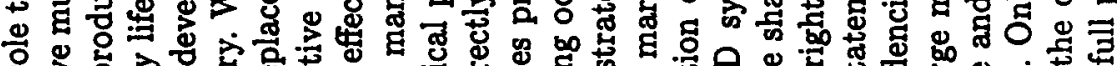

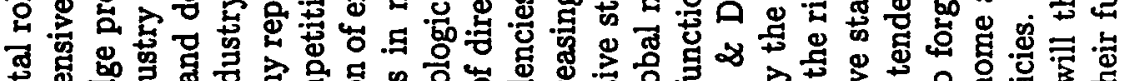

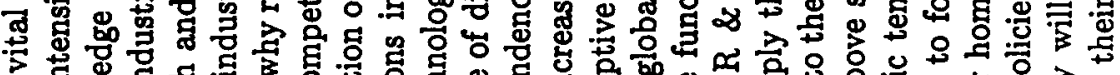

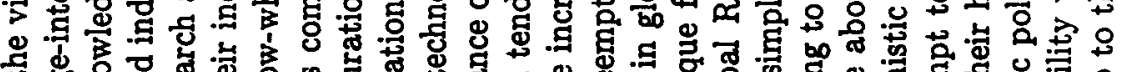

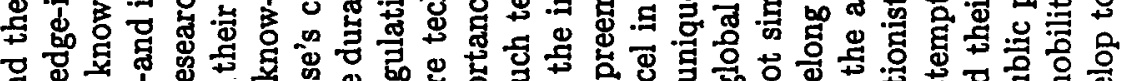

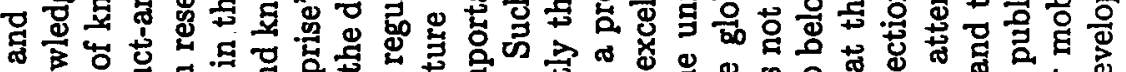

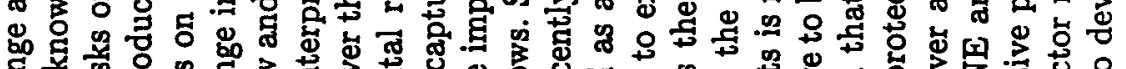

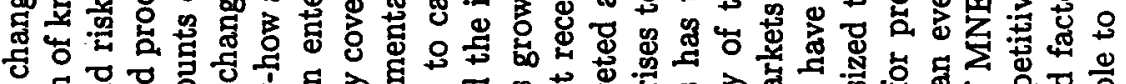

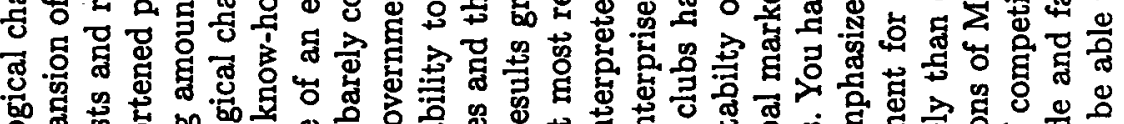

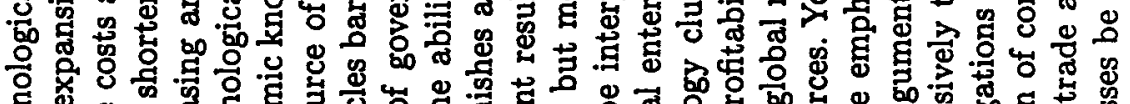

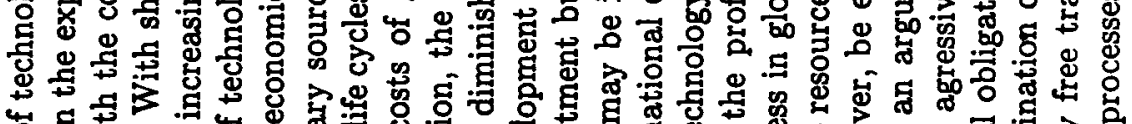

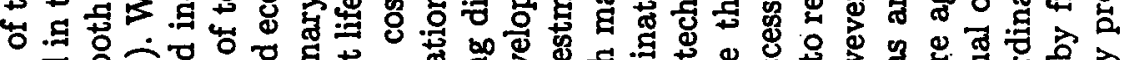

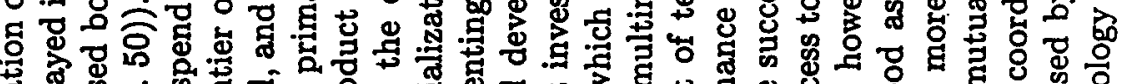

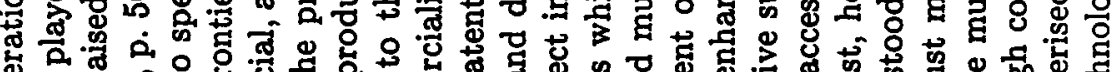

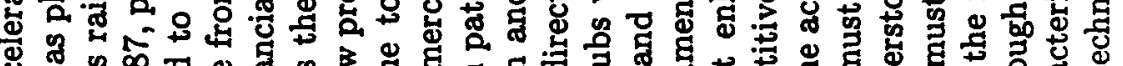

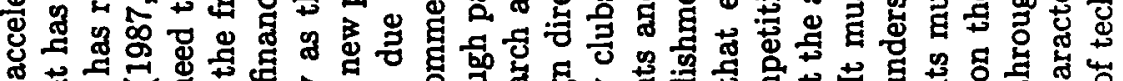

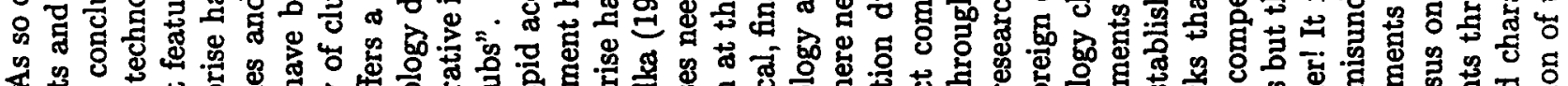

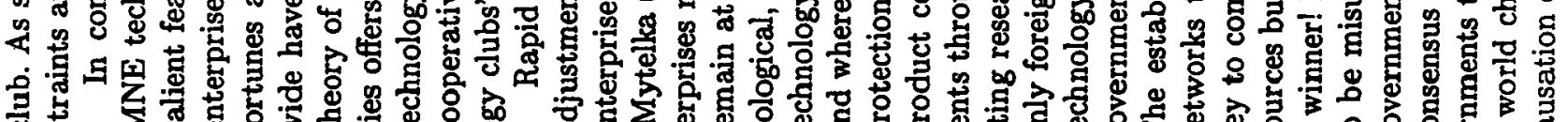

ำ 


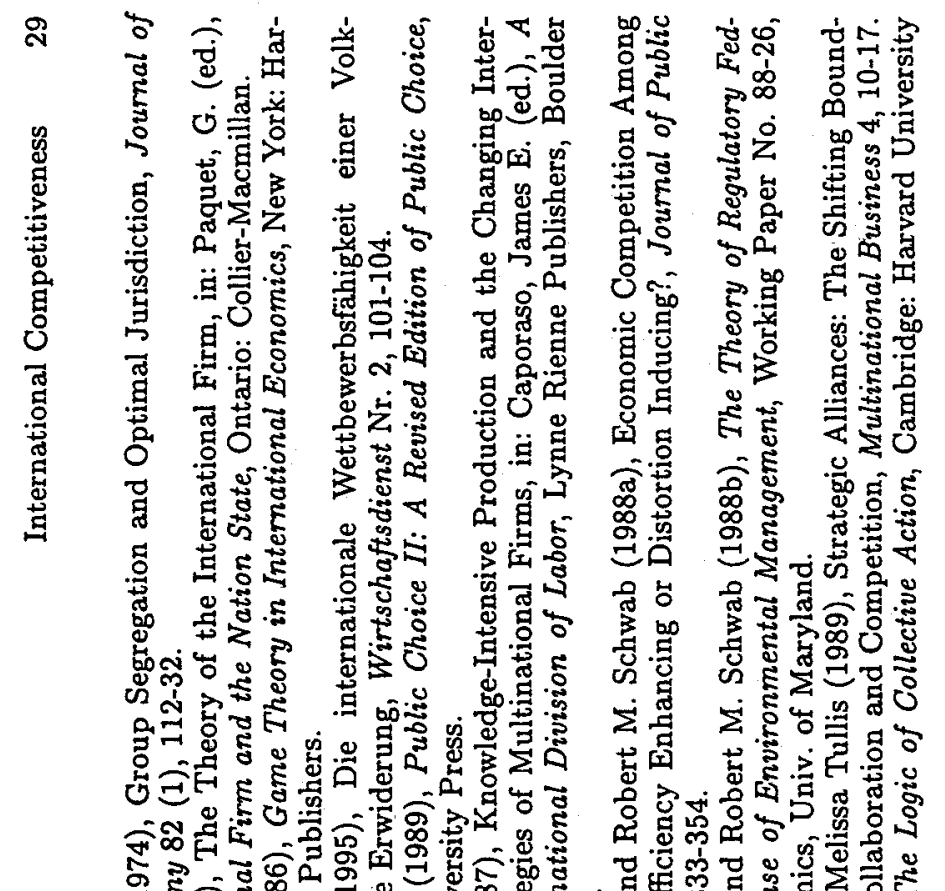

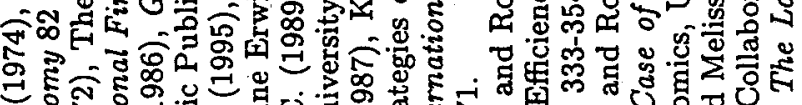

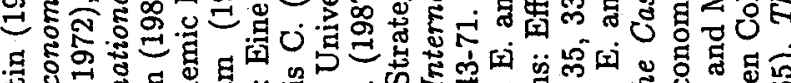
Tent

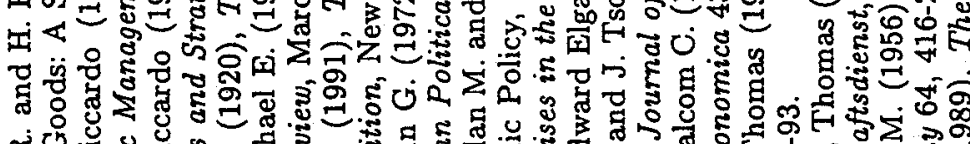

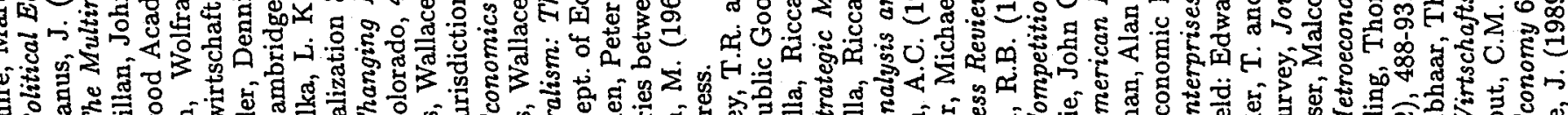

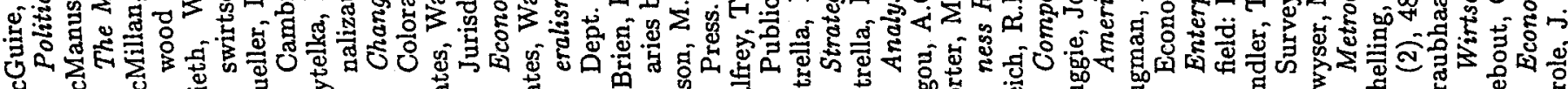

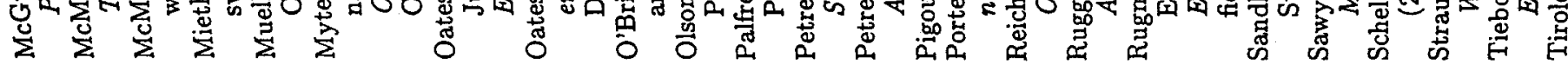

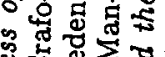

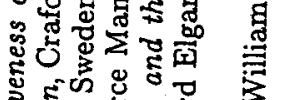

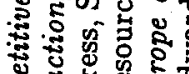

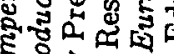

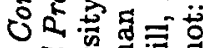

㑒

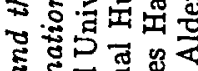

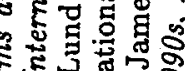

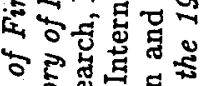

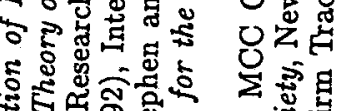

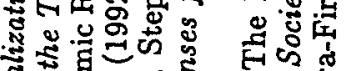

施

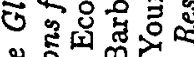

空.

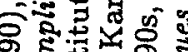

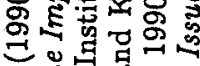

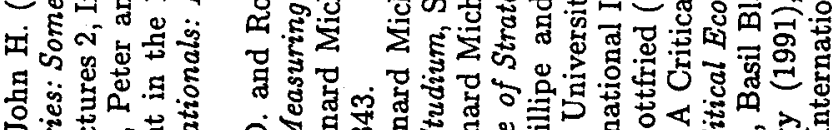

क占要

实

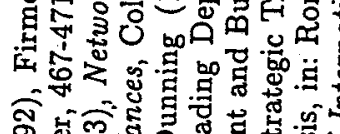

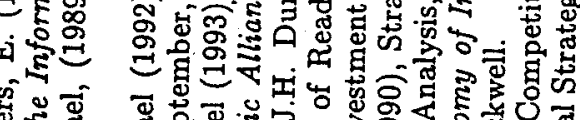

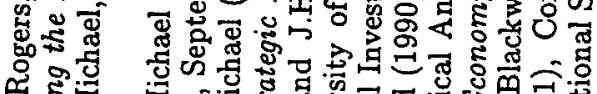

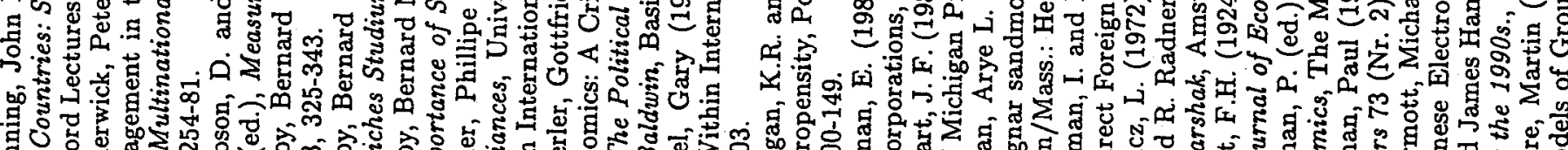

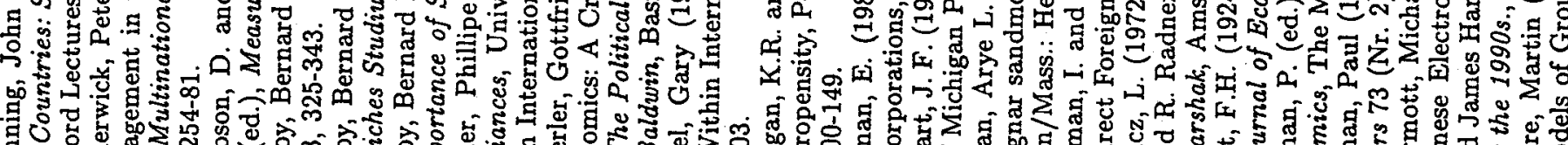

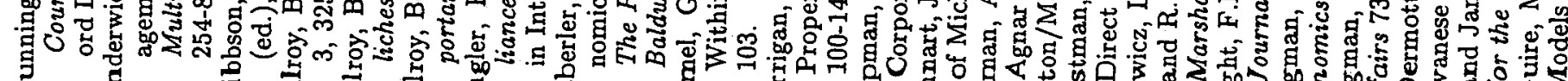
品 म 甶

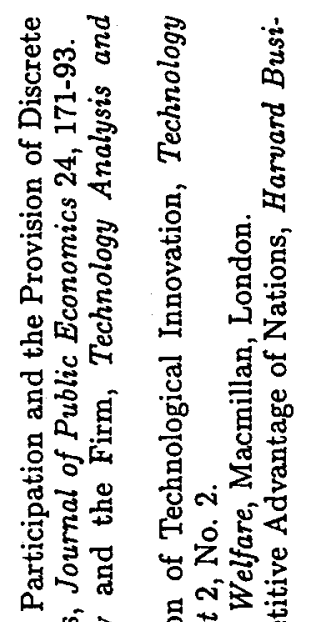

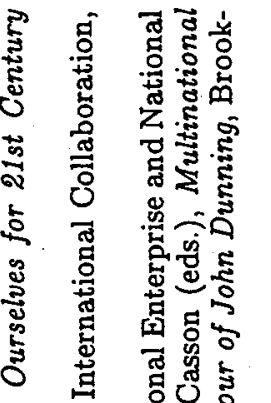

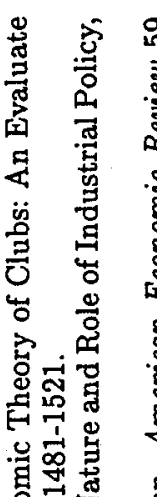

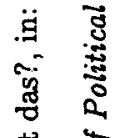

.

है

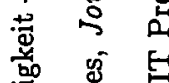

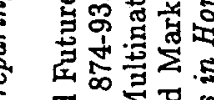

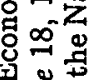

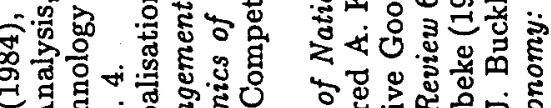
यद⿱

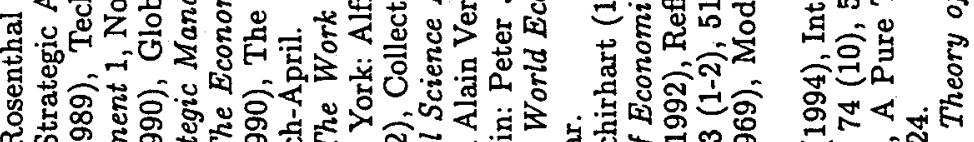

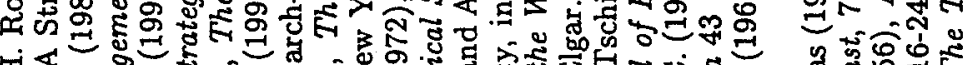

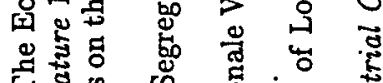

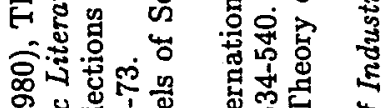

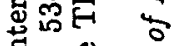




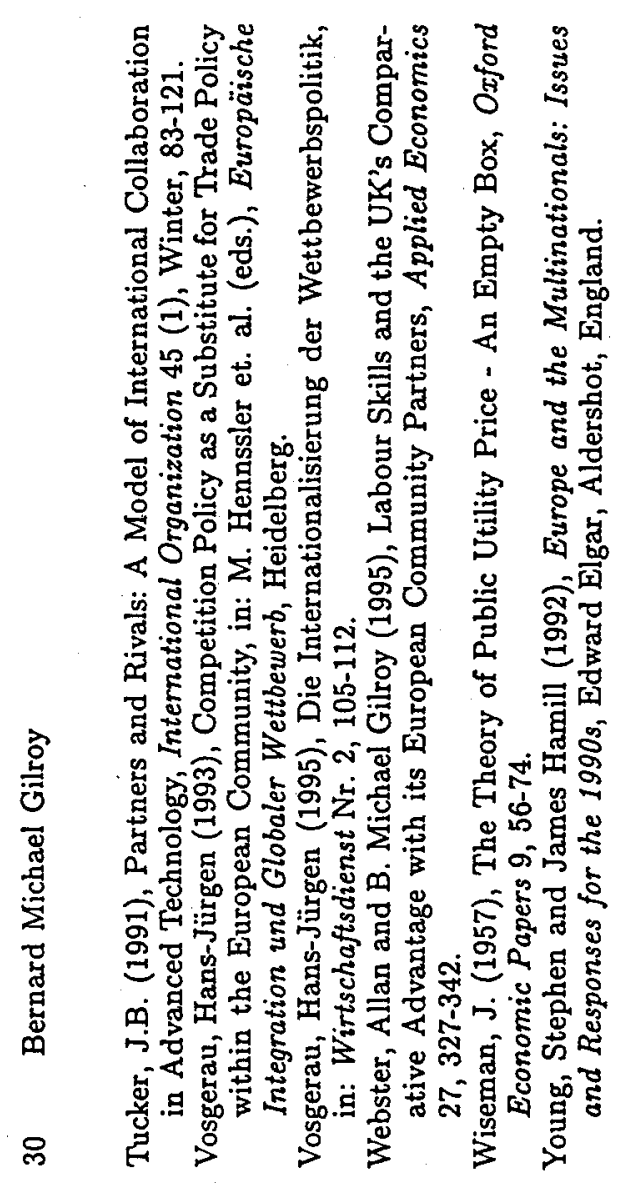

